\author{
Daniel MIDER
}

Instytut Badań nad Człowiekiem i Społeczeństwem im. Elżbiety Mider z d. Korzun

\title{
Potencjał delegitymizacji systemu politycznego w społeczeństwie polskim
}

\author{
The Potential for Deligitimization of the Polish Political System \\ in the Polish Society
}

\section{- Abstrakt •}

Delegitymizacja systemu politycznego stanowi silny czynnik indukujący istotne zaburzenia ładu politycznego, w tym użycia przemocy politycznej przez jednostki i grupy społeczne. W celu pomiaru potencjału tego zjawiska stworzono autorskie narzędzie wykorzystujące koncepcję typów idealnych i typów empirycznych Maxa Webera oraz Georga Jellinka. Ilościowych danych empirycznych dostarczyło Polskie Generalne Studium Wyborcze z 2011 roku. Przeprowadzono analizy różnic międzygrupowych wybranych zmiennych socjodemograficznych i psychograficznych. Wyodrębniono i zbadano następujące grupy: legitymizujących system polityczny (w pełni lub cząstkowo), ambiwalentnych wobec systemu politycznego, delegitymizujących (całkowicie i nie w pełni), a także kilka grup o umiarkowanym potencjale delegitymizacji (np. odrzucających demokrację, lecz wyrażających zadowolenie $\mathrm{z}$ instytucjonalnych aspektów jej funkcjonowania w praktyce politycznej). Uzyskane wyniki świadczą o umiarkowanym, lecz zauważalnym potencjale delegitymizacji polskiej demokracji; niektóre wyodrębnione kategorie społeczne mogą stanowić potencjalne zagrożenie dla bezpieczeństwa wewnętrznego.

\section{- Abstract •}

Delegitimization of the political system could be a strong factor leading to disruptions of the social and political order, including political violence. In order to measure the potential of this phenomenon an original measurement tool was created. The tool is based on the concept of ideal types and empirical types introduced by Max Weber and Georg Jellinek. Quantitative empirical data was provided by the Polish General Election Study (2011). Using this data, analyses of intergroup differences of selected sociodemographic and psychographic variables were carried out. The following groups emerged from the analyses: legitimizing the political system, ambivalent towards the political system, delegitimizing the political system (completely or incompletely), and several groups of moderate potential to delegitimize (for instance people rejecting democracy, but expressing satisfaction with the institutional aspects of its functioning in political practice). The gathered results confirm a moderate but noticeable potential for delegitimization of the Polish democracy; several extracted social categories may be a potential threat to internal security. 
Słowa kluczowe: legitymizacja systemu politycznego, delegitymizacja systemu politycznego, ład społeczny, przemoc polityczna
Keywords: legitimization of a political system, delegitimization of a political system, social order, political violence

\section{Wstęp}

Delegitymizacja systemu politycznego rozumiana jako brak lub niska akceptacja naczelnych zasad konstytuujących system polityczny przez obywateli, niski poziom aprobaty sposobu funkcjonowania systemu politycznego oraz deficyt poparcia dla instytucji systemu politycznego stanowi silny czynnik indukujący istotne zaburzenia ładu politycznego, w tym użycia przemocy politycznej. W celu pomiaru potencjału delegitymizacji systemu politycznego w społeczeństwie polskim wykorzystano autorskie narzędzie pomiaru, wykorzystujące koncepcję typów idealnych i typów empirycznych Maxa Webera (1904) oraz Georga Jellinka (1892, za: Kostrubiec, 2008). Ilościowych danych empirycznych do tego badania dostarczyło źródło danych wtórnych: Polskie Generalne Studium Wyborcze z 2011 roku (Markowski i in., 2012). Przeprowadzono analizy różnic międzygrupowych pod względem wybranych zmiennych socjodemograficznych i psychograficznych. Wyodrębniono i zbadano następujące grupy: legitymizujących system polityczny (w pełni lub cząstkowo), ambiwalentnych wobec systemu politycznego, delegitymizujących (całkowicie i nie w pełni), a także kilka grup o umiarkowanym potencjale delegitymizacji (np. odrzucających demokrację, lecz wyrażających zadowolenie z instytucjonalnych aspektów jej funkcjonowania w praktyce politycznej). Uzyskane wyniki świadczą o umiarkowanym, lecz zauważalnym potencjale delegitymizacji polskiej demokracji; niektóre wyodrębnione kategorie społeczne mogą stanowić potencjalne zagrożenie dla bezpieczeństwa wewnętrznego.

\section{Typologia postaw obywateli wobec systemu politycznego}

Model empiryczny badania postaw wobec systemu demokratycznego wykorzystuje koncepcję pojęć typologicznych wywodzących się z niemieckiej kultury metodologicznej (Kostrubiec, 1990; Woźniak, 1990). Tło teoretyczne wykorzystania koncepcji typów idealnych i typów empirycznych wyłożone zostało w pracy Demokracja późnej nowoczesności, gdzie obszernie nakreślono koncepcję Maxa Webera i Georga Jellinka (Błuszkowski, Mider, 2012). Z kolei w artykule Wymiar spoteczny konsolidacji demokracji w Polsce. Typologia postaw wobec systemu politycznego, 
zamieszczonym w tomie pod redakcją Jana Garlickiego (Mider, 2014), zaś wcześniej w artykule Partycypacja polityczna a legitymizacja systemu politycznego (2010), skonstruowałem typologię postaw wobec systemu politycznego a przetestowałem ją w niniejszej publikacji. W wymienionych jako dwie ostatnie publikacjach wyodrębniono - jako typy czyste - następujących pięć modelowych postaw wobec systemu politycznego, stanowiących narzędzie pomiaru stopnia legitymizacji lub delegitymizacji systemu politycznego:

- legitymizację pełną (legitymizacją czynną, całkowitą) rozumianą jako całkowite poparcie i wysoki poziom legitymizacji systemu politycznego. Ten typ legitymizacji przejawia się akceptacją norm konstytuujących system polityczny, pozytywną oceną jego funkcjonowania oraz legitymizowaniem systemu poprzez czynną partycypację polityczną;

- legitymizację niepełną (ułomną, wadliwą, pozorną, rytualna), której istotą jest niepełne, niekonsekwentne poparcie dla instytucji systemu politycznego, średni lub niski poziom legitymizacji systemu politycznego. Przejawia się ona akceptacją norm konstytuujących system polityczny, pozytywną oceną jego funkcjonowania, lecz brakiem podejmowania partycypacji lub uczestnictwem sporadycznym;

- legitymizację „krytyczną” przejawiającą się akceptacją norm konstytuujących system polityczny, lecz negatywną oceną jego funkcjonowania, realizującą różne strategie uczestnictwa w partycypacji konwencjonalnej (udziału w wyborach powszechnych);

- delegitymizację niepełną (którą można utożsamiać z apatią polityczną) charakteryzującą się indyferentną (ani negatywną, ani pozytywną) oceną wartości konstytuujących ład demokratyczny oraz funkcjonowania systemu politycznego, a także konsekwentnym brakiem partycypacji wyborczej;

- delegitymizację pełną (inaczej: delegitymizację czynną) rozumianą jako brak akceptacji norm konstytuujących system polityczny, negatywną oceną jego funkcjonowania oraz brak podejmowania konwencjonalnej partycypacji politycznej.

Po zidentyfikowaniu wymienionych wyżej postaw w literaturze przedmiotu dokonano zabiegu operacjonalizacji, a więc doboru i zdefiniowania wskaźników oraz zmiennych odpowiadających poszczególnym typom postaw, a także podjęto i uzasadniono decyzję co do metod analizy materiału empirycznego, wybierając miary statystyki opisowej i indukcyjnej. Następnie skonstruowane narzędzie wykorzystano do zbadania poziomu legitymizacji polskiej demokracji, wykorzystując do tego celu dane wtórne pochodzące z Polskiego Generalnego Studium Wyborczego z 2011 roku (Markowski i in., 2012). Cel podjętych analiz stanowiła próba 


\begin{tabular}{|c|c|c|c|c|}
\hline 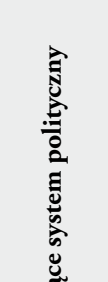 & 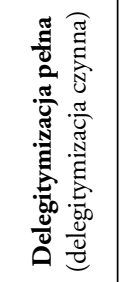 & 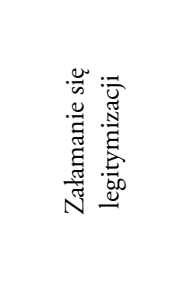 & 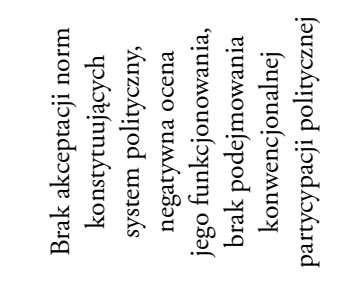 & 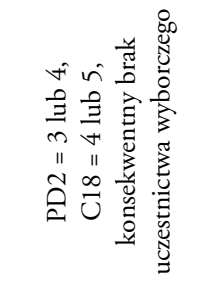 \\
\hline 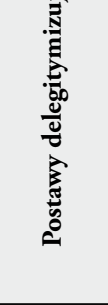 & 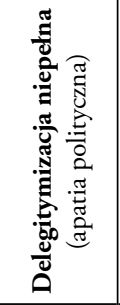 & 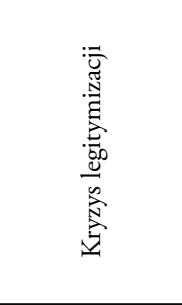 & 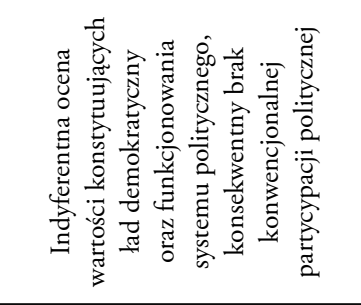 & 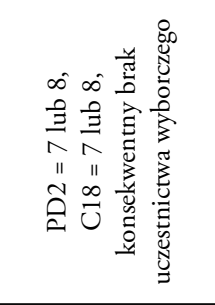 \\
\hline 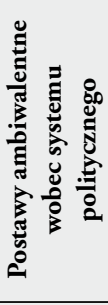 & 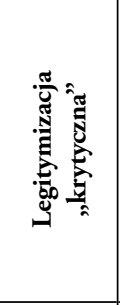 & 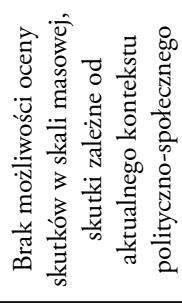 & 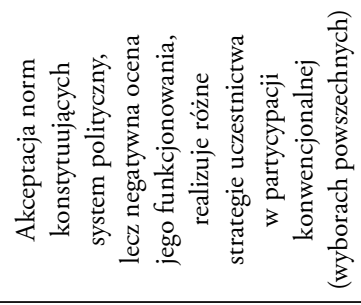 & 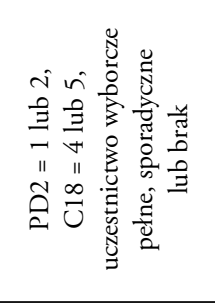 \\
\hline \multirow{2}{*}{ 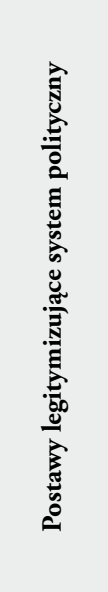 } & 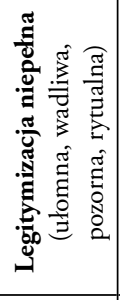 & 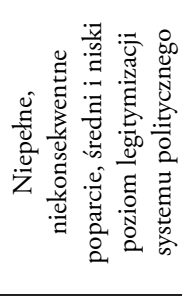 & 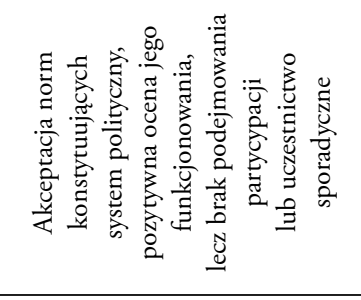 & 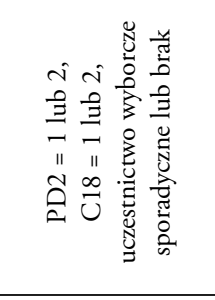 \\
\hline & 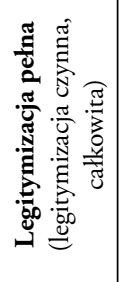 & 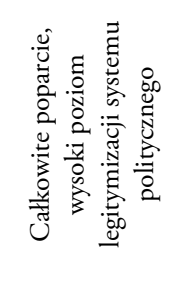 & 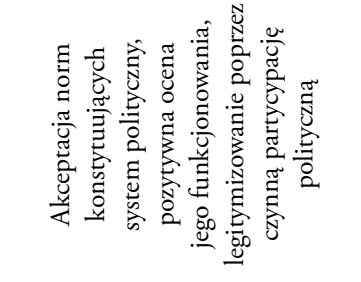 & 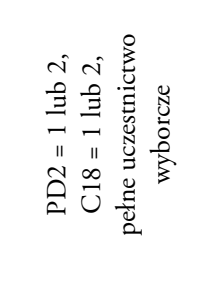 \\
\hline & 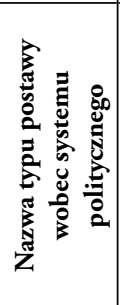 & 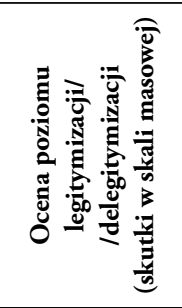 & 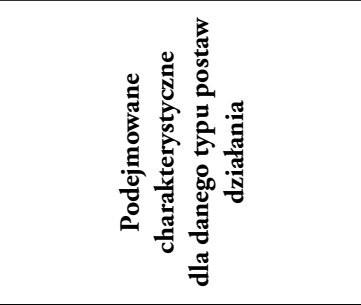 & 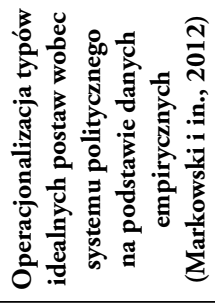 \\
\hline
\end{tabular}


rozpoznania podobieństw i różnic parametrów socjodemograficznych, socjopolitycznych i socjoekonomicznych pomiędzy Polakami należącymi do poszczególnych typów postaw. Liczebności i proporcje w ramach poszczególnych typów postaw wskazują na poziom legitymizacji polskiego systemu politycznego oraz jednocześnie na stopień legitymizacji polskiej demokracji w wymiarze społecznym.

\section{Operacjonalizacja typologii postaw wobec systemu politycznego}

W celu empirycznej weryfikacji poszczególnych typów idealnych wykorzystano dane pochodzące z badania ilościowego typu face-to-face Polskiego Generalnego Studium Wyborczego 2011 (grant NCN nr N N116 533740) kierowanego przez Radosława Markowskiego (2012). Wskaźnikami legitymizacji stały się następujące zmienne:

- akceptacja systemu demokratycznego jako najlepszego sposobu sprawowania władzy we wspólnotach politycznych:

PD2. W demokracji sa problemy, ale jest to lepszy system rzadzenia niż kazdy inny

$1-$ zdecydowanie zgadzam sie

2 - raczej zgadzam sie

3 - raczej nie zgadzam sie

$4-z$ decydowanie nie zgadzam sie

7 - trudno powiedzié́

8 -odmowa podania odpowiedzi

- dotyczącą funkcjonowania systemu politycznego w praktyce:

C18. Zadowolenie z funkcjonowania demokracji w Polsce

1 - zdecydowanie zadowolony(a)

2 - raczej zadowolony (a)

4 - raczej niezadowolony (a)

5 - zdecydowanie niezadowolony (a)

7- trudno powiedzieć

8 -odmowa odpowiedzi

- uczestnictwo w wyborach parlamentarnych w 2005, 2007 i 2011 roku (PH24. Udziat i glos w wyborach parlamentarnych we wrześniu 2005 r., C9. Udziat w poprzednich wyborach parlamentarnych w październiku 2007 roku oraz C8a. Czy głosowat(a) 9 października w wyborach parlamentarnych [2011 roku]). Zmienne sprowadzono do trzech następujących katego- 
rii: uczestnictwo intensywne (uczestnictwo we wszystkich wyborach, chyba że respondent nie był uprawniony); brak uczestnictwa (nie brał udziału w żadnych $\mathrm{z}$ wymienionych wyborów parlamentarnych, pomimo tego, że był uprawniony) oraz uczestnictwo o średnim stopniu natężenia (pozostałe sytuacje).

Wymienione zmienne posłużyły jako narzędzie klasyfikacyjne przyporządkowujące poszczególnych zbadanych respondentów przypadki do określonych typów. Zasady klasyfikacyjne zostały przedstawione w ostatnim wierszu tabeli 1.

Przyporządkowania jednostek analizy do poszczególnych typów pozwoliło na przejście do etapu analitycznego, w którym dokonano następujących czynności:

1) określenia liczebności i wzajemnych proporcji poszczególnych typów za pomocą analizy częstości danych tabelarycznych;

2) sporządzenia charakterystyk socjodemograficznych i psychograficznych wyodrębnionych kategorii z użyciem wybranych elementów statystyki opisowej (rozkładów tabelarycznych, wybranych miar tendencji centralnej oraz miar dyspersji);

3) określenia istotności różnic pomiędzy wyodrębnionymi typami z użyciem miary statystki indukcyjnej - testu chi-kwadrat dla jednej próby (testu dobroci dopasowania). Test ten pozwala orzec, czy rozkład badanej zmiennej istotnie różni się od rozkładu losowego lub innego rozkładu określonego przez badacza. Innymi słowy umożliwia on porównywanie grup pomiędzy sobą i stwierdzanie stochastycznej różnicy lub podobieństwa między nimi według schematu wspólnego testom statystycznym, uwzględniającego hipotezę zerową $\left(\mathrm{H}_{0}\right)$ i hipotezę alternatywną $\left(\mathrm{H}_{1}\right)$ :

$\mathrm{H}_{0}$ - zakładająca brak istotnej statystycznie różnicy pomiędzy porównywanymi grupami;

$\mathrm{H}_{1}$ - wykazująca istnienie statystycznie istotnej różnicy pomiędzy porównywanymi rozkładami empirycznymi.

Test przeprowadzono przyjmując maksymalne dopuszczalne prawdopodobieństwo popełnienia błędu I rodzaju na poziomie pięciu procent. Wynik testu dobroci dopasowania chi-kwadrat jest więc istotny statystycznie przy wartości $\mathrm{p} \leq 0,05$, co oznacza, że odrzucamy hipotezę zerową. Z kolei, jeśli wartość p przekroczy 0,05 oznacza to, że nie ma podstaw, by hipotezę zerową odrzucić, a co za tym idzie, stwierdzamy, że pomiędzy wartościami obserwowanymi a oczekiwanymi brak jest statystycznie istotnej różnicy.

Warunki zastosowania testu chi-kwadrat dla jednej próby są następujące: przeznaczony jest on dla zmiennej mierzonej na poziomie nominalnym (ale także porządkowym czy interwałowym) dla wystarczająco licznej próby. Za taką nale- 
ży uznać próbę liczącą co najmniej 30 lub 50 jednostek analizy (Yule, Kendall, 1966). Ponadto liczebności przypadające na poszczególne wartości zmiennej również powinny być wystarczające - na ogół podawane są liczby 5, 8 i 10 jednostek analizy (Sobczyk, 2002). Wymaga się również dużych liczebności oczekiwanych żadna nie może być mniejsza niż jeden, zaś nie więcej niż $20 \%$ może być mniejsza niż pięć (Cochran, 1952).

Test ten wybrano ze względu na fakt, że pozwala on na analizę zmiennych mierzonych na różnych skalach - od jakościowych do ilościowych, a ponadto nie wymaga on normalności rozkładu. Cechy te czynią go pożytecznym narzędziem statystycznym w naukach społecznych, gdzie zebrane dane rzadko osiągają normalność rozkładu i pomiar następuje na ogół na skalach jakościowych.

\section{Analiza typów postaw wobec systemu politycznego}

Przeprowadzona według powyższego schematu segmentacja pozwoliła zakwalifikować blisko 3/4 badanych z całego zbioru danych $(73,2 \%)$, co świadczy o względnie trafnie dobranych zasadach klasyfikacyjnych przyjętych dla typów idealnych. Liczebności w typach postaw, jak: legitymizacja pełna, legitymizacja niepełna oraz legitymizacja „krytyczna” okazały się najliczniejsze i zbliżone do siebie pod względem liczebności (odpowiednio: 21,2\%, 24,7\% i 27,4\%). Najmniej liczne kategorie to delegitymizacja pełna (zaledwie $0,8 \%$ ) oraz delegitymizacja niepełna $(1,1 \%)$. Niesklasyfikowana pozostała blisko czwarta część badanych (24,9\%).

Wstępna, niepogłębiona refleksja nad danymi pozwala na sformułowanie umiarkowanie optymistycznych wniosków na temat poziomu konsolidacji polskiej demokracji w wymiarze społecznym: do legitymizujących zakwalifikowano 45,9\% badanych, zaś kategoria delegitymizujących jest marginalna (1,9\%). Z drugiej strony niepokoić powinna najliczniejsza ze wszystkich wyodrębnionych typów grup legitymizujących „krytycznie” system polityczny: akceptujących demokrację, jednak niezadowolonych z funkcjonowania jej instytucji (27,3\% wskazań). Są to potencjalni kontestatorzy istniejącego ładu. Ponadto ostateczne orzeczenie co do stanu demokracji można wydać dopiero po przeanalizowaniu kategorii niesklasyfikowanych. Omówione wyniki zestawiono w tabeli 2. 
Tabela 2. Częstości występowania poszczególnych typów idealnych postaw w społeczeństwie polskim na podstawie danych PGSW 2011 (Markowski i in., 2012), N=1919

\begin{tabular}{|c|c|c|c|c|c|c|}
\hline \multirow{2}{*}{$\begin{array}{c} \\
\\
\text { Nazwa typu } \\
\text { postawy } \\
\text { wobec } \\
\text { systemu } \\
\text { politycznego }\end{array}$} & \multicolumn{2}{|c|}{$\begin{array}{l}\text { Postawy legitymizujące } \\
\text { system polityczny }\end{array}$} & \multirow{2}{*}{ 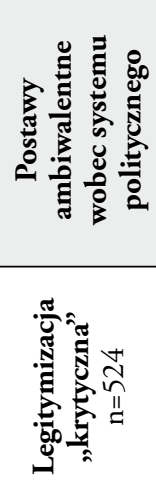 } & \multicolumn{2}{|c|}{$\begin{array}{c}\text { Postawy } \\
\text { delegitymizujące } \\
\text { system polityczny }\end{array}$} & \multirow{2}{*}{ 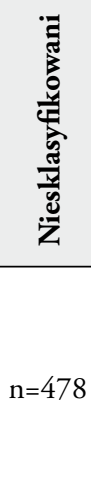 } \\
\hline & 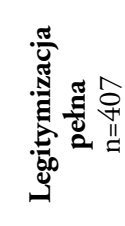 & 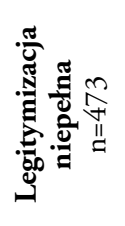 & & 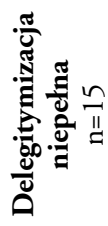 & 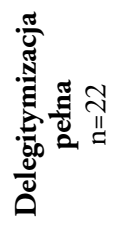 & \\
\hline $\begin{array}{l}\text { Częstości } \\
\text { (w proc.) }\end{array}$ & 21,2 & 24,7 & 27,4 & 0,8 & 1,1 & 24,9 \\
\hline
\end{tabular}

Źródło: opracowanie własne na podstawie Markowski, R. i in. (2012), Polskie Generalne Studium Wyborcze 2011 [PGSW].

W następnej części przeanalizowano wybrane charakterystyki socjodemograficzne i psychograficzne w ramach poszczególnych typów postaw. Pod uwagę wzięto następujące zmienne charakteryzujące badanych i według teorii stratyfikacji społecznej determinujące ich miejsce w strukturze klasowo-warstwowej współczesnego społeczeństwa:

- płeć [zmienna: PLEC]: mężczyzna, kobieta.

- wiek [zrekodowana zmienna: URODZONY]: młode pokolenie (18-35 lat), średnie pokolenie (35-60 lat), starsze pokolenie (powyżej 60 lat).

- wykształcenie [zrekodowana zmienna W1]: (zrekodowano na wykształcenie podstawowe, zawodowe, średnie, wyższe).

- wykonywany zawód [zrekodowana zmienna: W2]:

1. Właściciele i kadra zarządzająca (1 - dyrektorzy, prezesi i kadra kierownicza przedsiębiorstw, instytucji oraz administracji państwowej i samorządowej; 10 - właściciele i współwłaściciele firm, zakładów, punktów sprzedaży, ajenci i inni prowadzący dział. gospod. poza roln.);

2. Zawody twórcze i specjaliści z wyższym wykształceniem (2 - zawody twórcze i specjaliści z wyższym wykształceniem, inżynierowie, lekarze, prawnicy, nauczyciele);

3. Pracownicy administracyjno-biurowi i pracownicy usług, średni perso- 
nel techniczny (3 - technicy i inny średni personel, pielęgniarki, podoficerowie, policjanci; 4 - pracownicy administracyjno-biurowi, sekretarki, pracownicy poczty, recepcjoniści, telefoniści); 5 - pracownicy sklepów, punktów usługowych, usług osobistych, ochrony; konduktorzy, opiekunki dziecięce, kierowcy);

4. Robotnicy (6 - robotnicy wykwalifikowani i brygadziści zatrudnieni poza rolnictwem i leśnictwem; 7 - pracownicy wykonujący prace proste poza rolnictwem i leśnictwem, sprzątaczki, dozorcy, robotnicy pomocniczy; 8 - robotnicy najemni i brygadziści zatrudnieni w rolnictwie i leśnictwie, rybacy; 9 - rolnicy indywidualni i pomagający im członkowie rodzin);

5. Uczniowie i studenci (11 - uczniowie, studenci);

6. Emeryci i renciści (12 - renciści, 13 - emeryci);

7. Bezrobotni, zajmujący się domem i niepracujący z innych powodów (15 - zajmujący się domem, gospodynie domowe; 14 - bezrobotni; 16 niepracujący $\mathrm{z}$ innych powodów).

- dochód gospodarstwa domowego zrekodowany według następujących zasad:

1. bardzo niskie dochody (do 1000 PLN),

2. niskie dochody (powyżej 1000 do 2000 PLN),

3. umiarkowane dochody (powyżej 2000 do 3000 PLN),

4. wysokie dochody (powyżej 3000 do 5000 PLN),

5. bardzo wysokie dochody (powyżej 5000 PLN).

- wielkość miejsca zamieszkania (zrekodowana zmienna: KLM6):

1. Mieszkańcy wsi $(1-$ wieś),

2. Mieszkańcy małych i średnich miast do 100 tysięcy ludności $(2-$ miasto do 19 999; 3 - miasto od 20000 do 49 999; 4 - miasto od 50000 do 99 999),

3. Mieszkańcy dużych miast powyżej 100 tysięcy ludności $(5$ - miasto od 100000 do 499 999; 6 - miasto 500000 i więcej).

W procesie analiz brano również pod uwagę zmienne psychograficzne, które pozwoliły w sposób pogłębiony analizować postawy poszczególnych grup respondentów wobec systemu politycznego:

- stosunek do wiary i religii [zmienna M40 bez rekodowania]: niewierzący, mający wątpliwości w sprawach wiary, wierzący, głęboko wierzący, nie wie i odmawia odpowiedzi),

- orientacja ideologiczna [zrekodowana zmienna C15]:

1. lewica $(0,1,2,3)$, 
2. centrum $(4,5,6)$,

3. prawica $(7,8,9,10)$,

4. pogląd, że lewica i prawica nie istnieją.

- a także - jako pomocnicze - inne zmienne: PO92A. Polsce potrzebny jest silny odnowiciel; PO92B. W Polsce nieliczni zawłaszczają władzę przynależną zwykłym ludziom; PO92C. jest ostatnia chwila, by uchronić Polskę przed katastrofą; PP66. Pogląd na temat codziennego przestrzegania prawa w życiu; PO92C. jest ostatnia chwila, by uchronić Polskę przed katastrofą; PE45A. Ocena obecnej sytuacji politycznej w Polsce; PE45B. Ocena obecnej sytuacji gospodarczej w Polsce. 


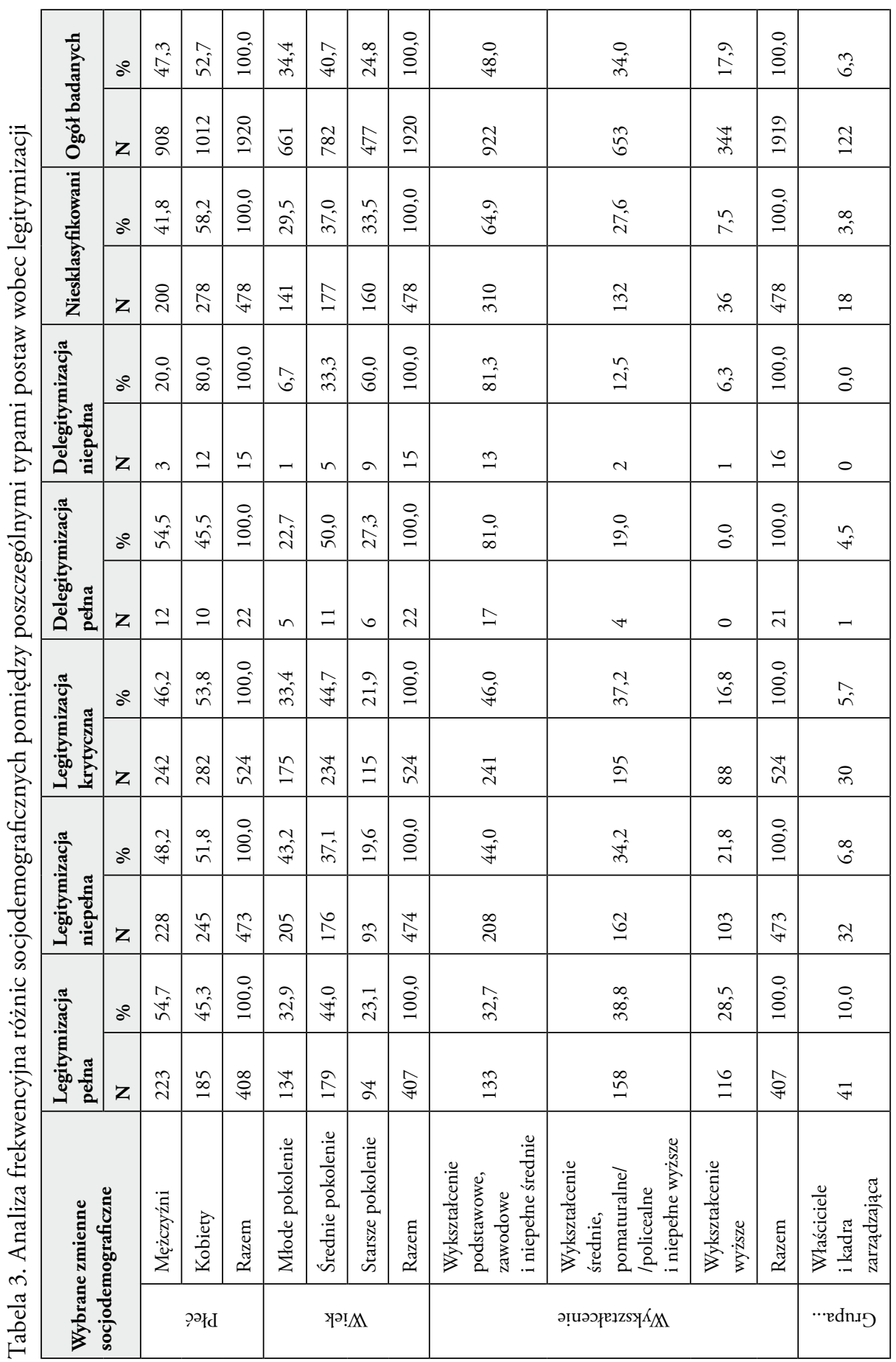




\begin{tabular}{|c|c|c|c|c|c|c|c|c|c|c|}
\hline \multirow{2}{*}{ 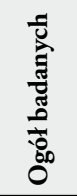 } & $a^{e}$ & $\stackrel{\sqrt[H]{n}}{N}$ & $\stackrel{\stackrel{n}{n}}{n}$ & $\hat{\tilde{\mathrm{N}}}$ & $\stackrel{\circ}{\wedge}$ & $\begin{array}{l}\text { ô } \\
\hat{n}\end{array}$ & $\stackrel{0}{=}$ & $\begin{array}{l}0 \\
8 \\
0\end{array}$ & $\hat{\tilde{n}}$ & $\overrightarrow{\hat{n}}$ \\
\hline & $\mathbf{z}$ & $\stackrel{\stackrel{P}{\beth}}{ }$ & ৯े & $\begin{array}{l}\stackrel{\overbrace{}}{\sim} \\
\stackrel{+}{+}\end{array}$ & $\stackrel{+}{2}$ & $\stackrel{\infty}{\stackrel{\infty}{n}}$ & $\stackrel{\sim}{\sim}$ & $\underset{\widetilde{\Omega}}{\beth}$ & $\mathbb{N}$ & $\begin{array}{l}\stackrel{\sigma}{\sigma} \\
\end{array}$ \\
\hline \multirow{2}{*}{ 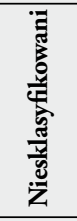 } & $a^{\circ}$ & $\stackrel{\infty}{\stackrel{\infty}{f}}$ & $\stackrel{\star}{a}$ & $\hat{\tilde{v}}$ & $\approx$ & $\stackrel{\sim}{\tilde{m}}$ & $\hat{\jmath}$ & $\stackrel{0}{8}$ & 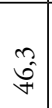 & $\begin{array}{l}0 \\
\text { in }\end{array}$ \\
\hline & $\mathbf{z}$ & $\stackrel{\sim}{\sim}$ & 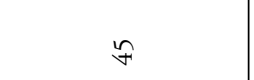 & $\stackrel{\infty}{\circ}$ & $\stackrel{n}{n}$ & $\stackrel{\infty}{\infty}$ & $\varpi$ & $\underset{\forall}{\curvearrowright}$ & $\overrightarrow{\widetilde{N}}$ & 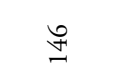 \\
\hline \multirow{2}{*}{ 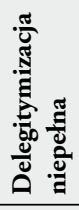 } & $\circ$ & Oे & $\stackrel{m}{n}$ & $\begin{array}{l}0 \\
\dot{i}\end{array}$ & $\hat{\sigma}$ & $\hat{n}^{n}$ & $\hat{\sigma}$ & $\begin{array}{l}0 \\
8 \\
0\end{array}$ & $\hat{\sigma}$ & $\stackrel{m}{=}$ \\
\hline & $z$ & 0 & N & $n$ & $\neg$ & $\infty$ & $\neg$ & $\cong$ & $\stackrel{-}{\circ}$ & $\sim$ \\
\hline \multirow{2}{*}{ 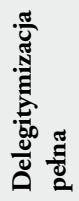 } & $\circ$ & $\stackrel{0}{0}$ & $\begin{array}{l}0 \\
\stackrel{2}{=}\end{array}$ & $\begin{array}{l}\approx \\
\approx \\
\approx\end{array}$ & $\ddot{0}$ & $\stackrel{n}{\stackrel{\sim}{2}}$ & $\vec{a}$ & $\begin{array}{l}0 \\
\dot{0}\end{array}$ & $\begin{array}{l}\hat{\sigma} \\
\hat{\sigma}\end{array}$ & 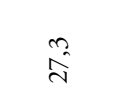 \\
\hline & z & 0 & $n$ & $\circ$ & 0 & $\bullet$ & $\sim$ & ה & $\curvearrowleft$ & $\bullet$ \\
\hline \multirow{2}{*}{ 宽 } & $\circ$ & $\stackrel{+t}{N}$ & $\hat{\sigma}$ & $\begin{array}{c}\stackrel{m}{+} \\
\stackrel{+}{d}\end{array}$ & ņ & $\hat{\stackrel{N}{\hat{~}}}$ & $\begin{array}{l}0 \\
\stackrel{0}{0}\end{array}$ & $\begin{array}{l}0 \\
\dot{8}\end{array}$ & $\overrightarrow{n^{0}}$ & तิ \\
\hline & $z$ & $\hat{m}$ & $\infty$ & 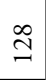 & $\ddot{n}$ & $\vec{n}$ & $\stackrel{\imath}{n}$ & $\stackrel{\overrightarrow{1}}{n}$ & $\stackrel{\infty}{-}$ & $\stackrel{N}{I}$ \\
\hline \multirow{2}{*}{ 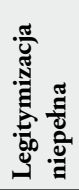 } & 。 & $\stackrel{\circ}{\wedge}$ & हे & $\begin{array}{l}\infty \\
\stackrel{\mathrm{N}}{ }\end{array}$ & $\underset{\forall}{*}$ & $\stackrel{\text { むे }}{\mathrm{d}}$ & $\stackrel{m}{\sim}$ & $\stackrel{0}{8}$ & $\begin{array}{l}0 \\
0 \\
0 \\
n\end{array}$ & $\begin{array}{l}\infty \\
\hat{n}\end{array}$ \\
\hline & z & $\stackrel{n}{1}$ & ฉે & $\stackrel{\infty}{0}$ & 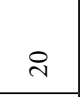 & $\stackrel{\infty}{=}$ & $\tilde{\sigma}$ & $\stackrel{\Re}{\stackrel{\overbrace{}}{\forall}}$ & $\stackrel{\cong}{\bumpeq}$ & $\stackrel{8}{0}$ \\
\hline \multirow{2}{*}{ 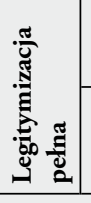 } & $\therefore$ & $\stackrel{\infty}{=}$ & $\stackrel{\sim}{\underset{f}{*}}$ & $\begin{array}{l}\stackrel{n}{2} \\
\stackrel{2}{2}\end{array}$ & $\stackrel{\infty}{0}$ & $\hat{\widehat{d}}$ & $\vec{n}$ & $\begin{array}{l}0 \\
8\end{array}$ & $\hat{\imath}$ & $\vec{m}$ \\
\hline & $\mathbf{z}$ & $\stackrel{\infty}{+}$ & $\stackrel{\infty}{n}$ & $\curvearrowright$ & $\stackrel{\leftrightarrow}{*}$ & $\stackrel{\circ}{0}$ & নे & $\begin{array}{l}\infty \\
\stackrel{+}{+}\end{array}$ & $\stackrel{\beth}{\beth}$ & 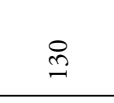 \\
\hline \multirow{2}{*}{\multicolumn{2}{|c|}{ 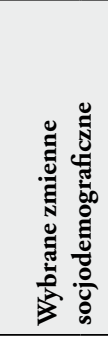 }} & 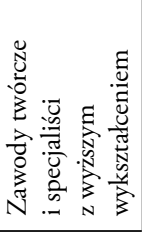 & 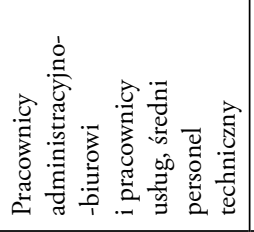 & 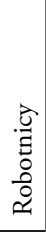 & 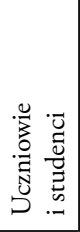 & 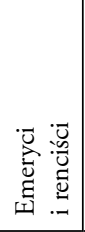 & 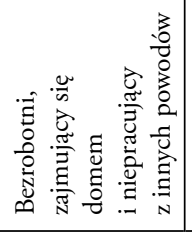 & 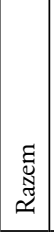 & 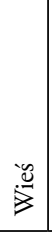 & 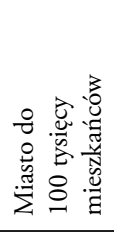 \\
\hline & & \multicolumn{7}{|c|}{ еморомеz-оuzэәюоds edn.গ } & \multicolumn{2}{|c|}{ 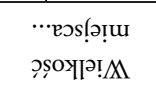 } \\
\hline
\end{tabular}




\begin{tabular}{|c|c|c|c|c|c|c|c|c|c|c|c|c|c|c|c|c|}
\hline \multirow{2}{*}{ 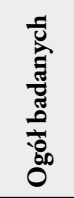 } & $0^{0}$ & ڤ̂ & $\stackrel{0}{8}$ & $\begin{array}{l}\infty \\
\hat{\sim}\end{array}$ & $\hat{m}^{n}$ & $\hat{\tilde{i}}$ & $\tilde{\sigma}$ & $\hat{n}$ & $\stackrel{0}{8}$ & 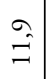 & 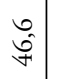 & $\begin{array}{l}\hat{\delta} \\
\hat{n}\end{array}$ & $\stackrel{\infty}{\infty}$ & $\ddot{8}$ & $\vec{f}$ & $\tilde{\sigma}$ \\
\hline & $\mathbf{z}$ & $\stackrel{\curvearrowright}{n}$ & $\hat{\Xi}$ & $\stackrel{\sim}{\sim}$ & ஸి & 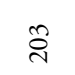 & $\stackrel{\overbrace{}}{0}$ & $\stackrel{\infty}{n}$ & Д̆ & $\stackrel{\sim}{\stackrel{n}{2}}$ & $\vec{\infty}$ & तु & ळ & $\stackrel{\text { ก }}{ }$ & $\hat{\lambda}$ & $\stackrel{+N}{\stackrel{H}{\prime}}$ \\
\hline \multirow{2}{*}{ 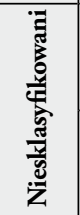 } & $0^{\circ}$ & $\overrightarrow{\tilde{v}}$ & $\stackrel{0}{8}$ & $\tilde{n}^{n}$ & $\hat{n}$ & ${\stackrel{\infty}{\underbrace{-}}}^{-1}$ & $\begin{array}{l}0 \\
\infty\end{array}$ & $\nRightarrow$ & $\begin{array}{l}0 \\
\stackrel{8}{8}\end{array}$ & $\hat{ \pm}$ & 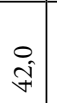 & के & $\hat{\infty}$ & $\stackrel{0}{8}$ & $\begin{array}{l}0 \\
i\end{array}$ & $\underbrace{\infty}_{0}$ \\
\hline & z & $\stackrel{\circ}{=}$ & $\stackrel{\curvearrowright}{\star}$ & ळ & $\infty$ & ळे & $\stackrel{\sim}{\sim}$ & 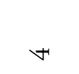 & $\stackrel{\widetilde{\sim}}{ }$ & $\hat{n}$ & $\sqrt{6}$ & $\hat{n}$ & $\stackrel{m}{m}$ & $\tilde{m}$ & $\simeq$ & กี \\
\hline \multirow{2}{*}{ 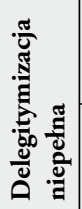 } & $0^{\circ}$ & $\stackrel{0}{\hat{i}}$ & $\begin{array}{l}0 \\
8 \\
8\end{array}$ & $\stackrel{+}{i}$ & $\begin{array}{l}0 \\
\overbrace{}^{\circ} \\
\stackrel{N}{n}\end{array}$ & $\begin{array}{l}0 \\
0\end{array}$ & : & $\ddot{0}$ & $\stackrel{\circ}{\circ}$ & $\Rightarrow$ & $\hat{n}^{m}$ & $\exists$ & $\underset{f}{\stackrel{*}{*}}$ & $\stackrel{0}{0}$ & $\hat{\sigma}$ & $\stackrel{0}{0}$ \\
\hline & $z$ & $n$ & $\cong$ & $n$ & N & 0 & 0 & 0 & $\lambda$ & - & $n$ & - & H & $a$ & - & 0 \\
\hline \multirow{2}{*}{ 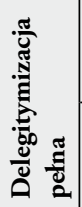 } & $0^{\circ}$ & $\stackrel{\infty}{\vec{m}}$ & $\stackrel{0}{8}$ & $\begin{array}{l}0 \\
\ddot{v}\end{array}$ & $\hat{\tilde{I}}$ & $\hat{\tilde{n}}$ & $\hat{\imath}$ & $\hat{\tilde{y}}$ & $\begin{array}{l}0 \\
\stackrel{8}{0}\end{array}$ & $\hat{\vec{N}}$ & $\begin{array}{l}\hat{\sigma} \\
\hat{\sigma}\end{array}$ & $\stackrel{m}{n}$ & $\stackrel{m}{\tilde{n}^{2}}$ & $\stackrel{0}{8}$ & $\approx$ & $\vec{a}$ \\
\hline & Z & $\lambda$ & $\tilde{\sim}$ & N & - & $n$ & - & - & $\infty$ & 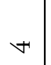 & $\wedge$ & $N$ & N & $\cong$ & - & $N$ \\
\hline \multirow{2}{*}{ 宽 } & $0^{\circ}$ & $\frac{0}{n}$ & $\stackrel{0}{8}$ & $\overrightarrow{\tilde{v}}$ & $\overrightarrow{\text { fै }}$ & $\begin{array}{l}\stackrel{+}{\mathrm{d}} \\
\hat{\mathrm{N}}\end{array}$ & $\begin{array}{l}0 \\
\infty \\
-1\end{array}$ & $\stackrel{\star n}{\sim}$ & $\begin{array}{l}0 \\
\stackrel{8}{8}\end{array}$ & $\begin{array}{l}0 \\
\mathfrak{I}\end{array}$ & $\underset{\sim}{\tilde{f}}$ & $\begin{array}{l}m \\
\infty \\
\infty\end{array}$ & $\stackrel{\circ}{\forall}$ & $\stackrel{0}{8}$ & $\stackrel{m}{*}$ & 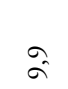 \\
\hline & z & స్ర & $\tilde{\hat{n}}$ & $\approx$ & $\infty$ & $\hat{n}$ & $\stackrel{ }{\forall}$ & $\bullet$ & $\stackrel{n}{\approx}$ & 8 & $\underset{\sim}{\vec{v}}$ & $\stackrel{\infty}{\infty}$ & $\curvearrowright$ & $\stackrel{\infty}{\stackrel{\infty}{\forall}}$ & ป & $\vec{n}$ \\
\hline \multirow{2}{*}{ 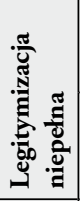 } & $0^{\circ}$ & $\ddot{\vartheta}_{\hat{\lambda}}^{0}$ & $\stackrel{0}{8}$ & $\hat{\hat{\nu}}$ & กี & $\begin{array}{l}\stackrel{+}{\mathrm{i}} \\
\hat{\mathrm{N}}\end{array}$ & $\overbrace{0}^{n}$ & $\begin{array}{l}0 \\
\infty\end{array}$ & $\stackrel{0}{\stackrel{0}{0}}$ & $\stackrel{0}{0}$ & $\vec{n}$ & $\overrightarrow{\hat{n}}$ & $\hat{\forall}$ & $\begin{array}{l}0 \\
8 \\
8\end{array}$ & $\approx$ & $\ddot{\sigma}$ \\
\hline & z & $\stackrel{ }{ \pm}$ & 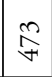 & $n$ & $\approx$ & $\approx$ & $\stackrel{\leftrightarrow}{\forall}$ & $\vec{\sim}$ & $\tilde{\Xi}$ & $\mathscr{F}$ & $\stackrel{\sim}{\sim}$ & తิ & 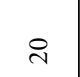 & $\stackrel{\infty}{\underset{\sim}{*}}$ & $\vec{\sim}$ & $\stackrel{F}{F}$ \\
\hline \multirow{2}{*}{ 宽 } & $0^{\circ}$ & $\begin{array}{l}0 \\
\infty^{0} \\
n\end{array}$ & $\begin{array}{l}0 \\
\stackrel{8}{0}\end{array}$ & 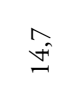 & î & 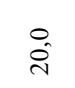 & $\begin{array}{l}0 \\
\stackrel{\sim}{v}\end{array}$ & $\begin{array}{l}\stackrel{0}{=} \\
=\end{array}$ & $\stackrel{0}{8}$ & $\overrightarrow{0}$ & $\begin{array}{l}\infty \\
\stackrel{\sim}{+}\end{array}$ & $\stackrel{n}{\sim}$ & $\begin{array}{l}\infty \\
0\end{array}$ & $\stackrel{0}{8}$ & in & 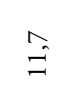 \\
\hline & $\mathbf{z}$ & $\hat{n}$ & ôे & $m$ & $\infty$ & $\mathscr{F}$ & $\approx$ & $\stackrel{\sim}{\sim}$ & 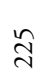 & 아 & $\stackrel{ \pm}{\stackrel{+}{二}}$ & $\stackrel{\infty}{\infty}$ & $n$ & $\hat{\bar{m}}$ & ㄱ. & $\stackrel{F}{F}$ \\
\hline \multirow{2}{*}{\multicolumn{2}{|c|}{ 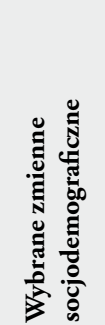 }} & 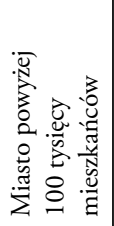 & 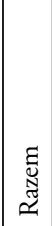 & 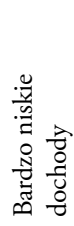 & 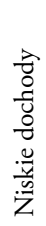 & 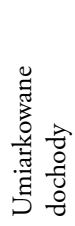 & 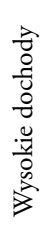 & 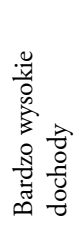 & $\begin{array}{l}\text { घ్ } \\
\widetilde{\widetilde{U}} \\
\text {. }\end{array}$ & 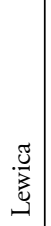 & 壹 & 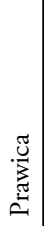 & 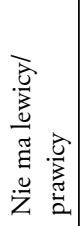 & $\begin{array}{l}\text { E్ } \\
\text { בू }\end{array}$ & 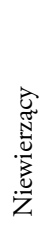 & 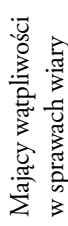 \\
\hline & & 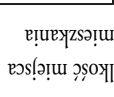 & & оळวM & & 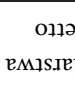 & & 8 рочр & & & $\begin{array}{r}\mathrm{e} \\
\mathrm{M}\end{array}$ & & $\begin{array}{l}\text { Id - } \\
\text { eu Kpe }\left.\right|^{c}\end{array}$ & & & $\begin{array}{l}\text { op } \\
\text { isotS }\end{array}$ \\
\hline
\end{tabular}



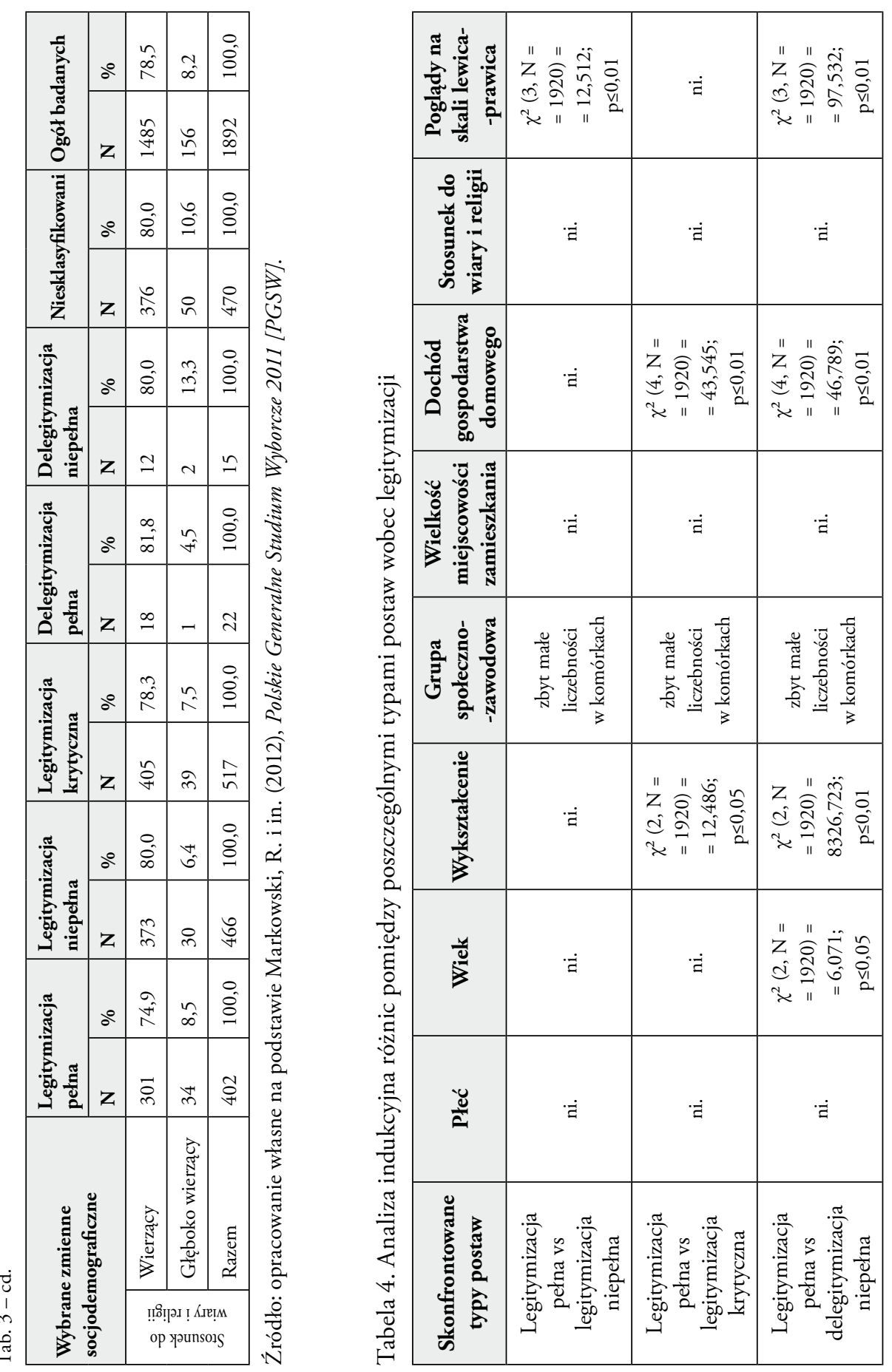


\begin{tabular}{|c|c|c|c|c|c|c|}
\hline 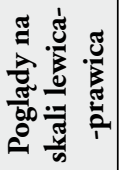 & 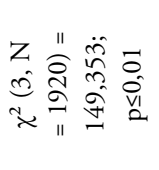 & 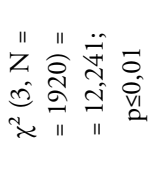 & $\dot{\vec{a}}$ & 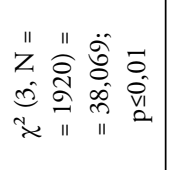 & 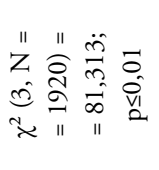 & $\cdot \overrightarrow{\vec{\theta}}$ \\
\hline 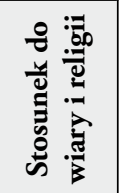 & 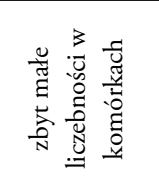 & $\dot{\vec{a}}$ & $\cdot \dot{\vec{a}}$ & $\cdot \dot{a}$ & 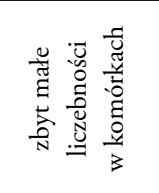 & $\dot{\vec{a}}$ \\
\hline 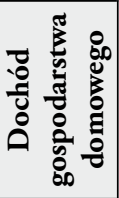 & 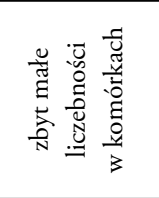 & 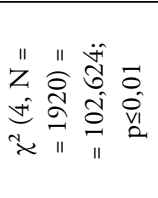 & 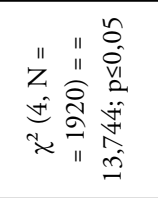 & 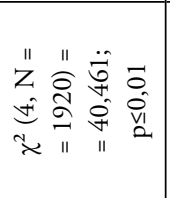 & 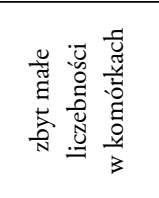 & 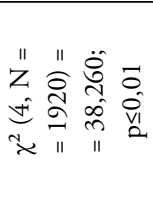 \\
\hline 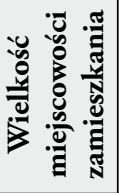 & 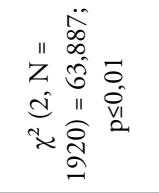 & 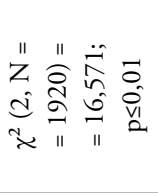 & $\cdot \dot{a}$ & $\dot{\vec{a}}$ & 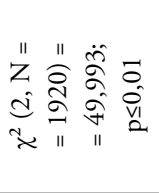 & $\cdot \vec{\exists}$ \\
\hline 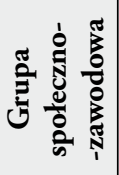 & 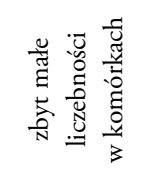 & 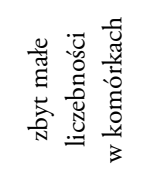 & 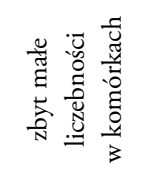 & 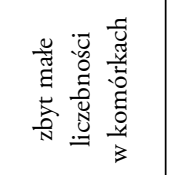 & 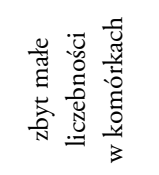 & 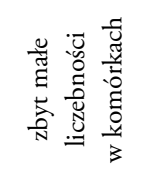 \\
\hline$\frac{\frac{0}{3}}{\frac{0}{\tilde{E}}}$ & 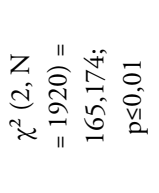 & 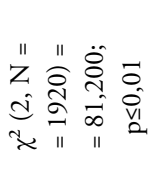 & $\dot{\vec{\theta}}$ & 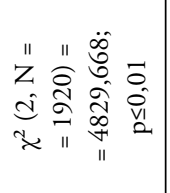 & 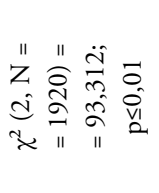 & 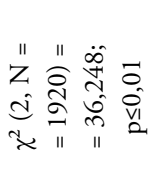 \\
\hline 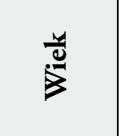 & 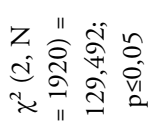 & 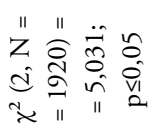 & · & 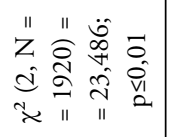 & 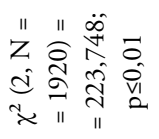 & 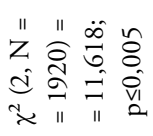 \\
\hline$\frac{\mathscr{u}}{\bar{E}}$ & 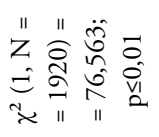 & 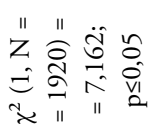 & $\cdot \vec{a}$ & · $\vec{\exists}$ & 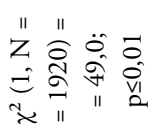 & $\cdot \dot{\vec{E}}$ \\
\hline 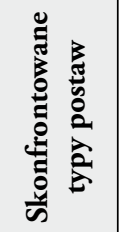 & 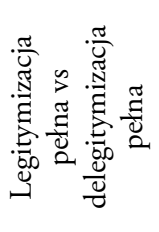 & 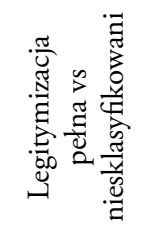 & 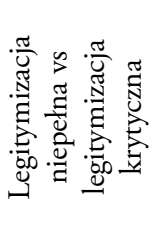 & 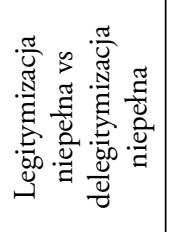 & 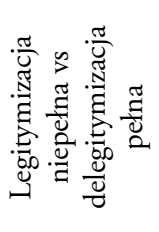 & 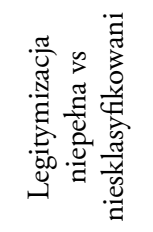 \\
\hline
\end{tabular}




\begin{tabular}{|c|c|c|c|c|c|c|}
\hline 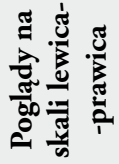 & 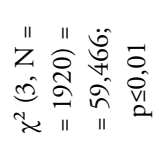 & 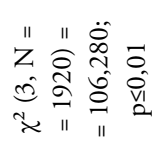 & $\vec{a}$ & 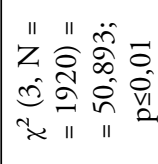 & 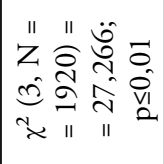 & 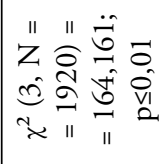 \\
\hline 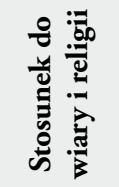 & $\ddot{\vec{a}}$ & 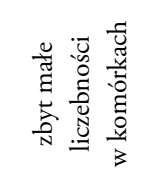 & $\dot{\vec{a}}$ & 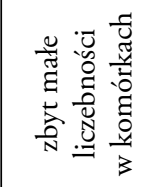 & $\dot{\vec{z}}$ & 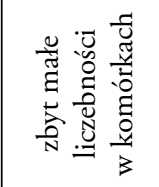 \\
\hline 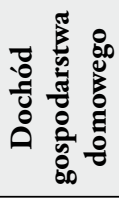 & 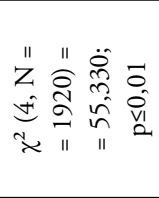 & 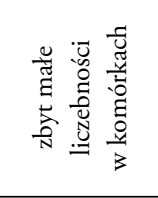 & 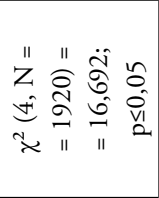 & 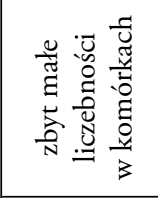 & 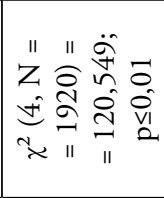 & 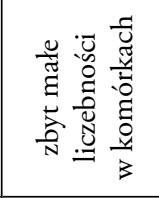 \\
\hline 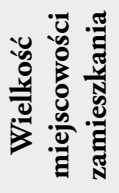 & $\cdot \dot{\vec{a}}$ & 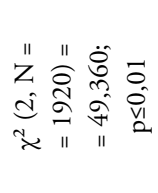 & $\ddot{a}$ & 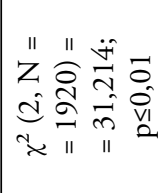 & $\cdot \overrightarrow{\vec{a}}$ & 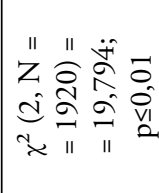 \\
\hline 递察 & 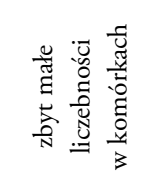 & 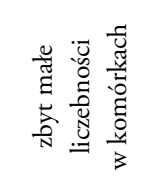 & 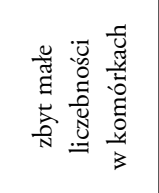 & 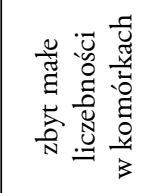 & 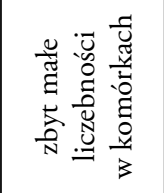 & 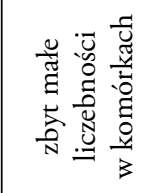 \\
\hline 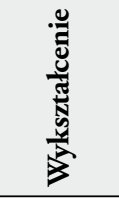 & 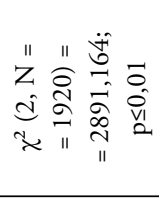 & 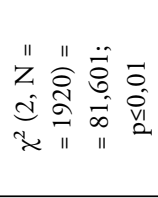 & 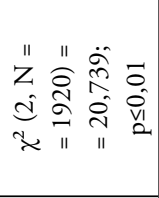 & 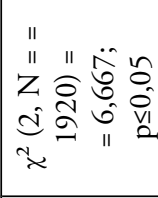 & 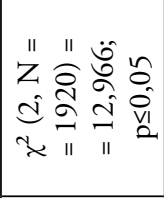 & 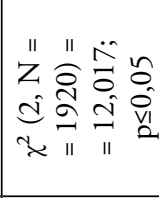 \\
\hline 光 & 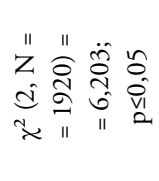 & 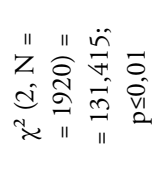 & 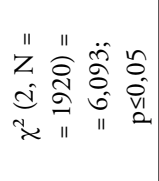 & 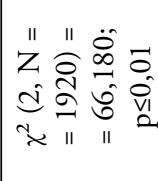 & 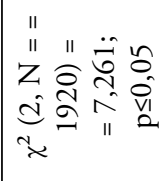 & 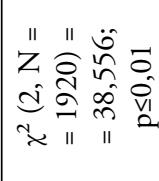 \\
\hline$\frac{\mathscr{y}}{2}$ & $\dot{\vec{a}}$ & 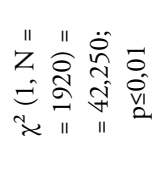 & a & 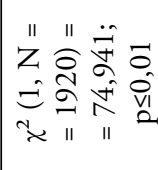 & 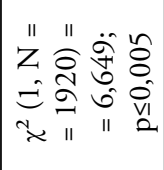 & 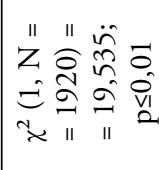 \\
\hline 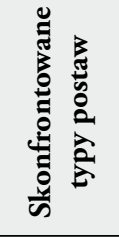 & 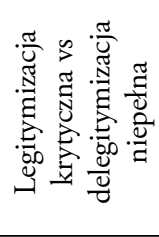 & 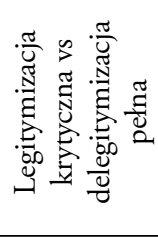 & 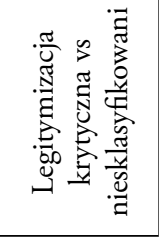 & 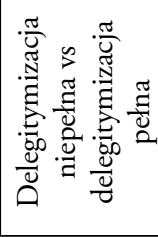 & 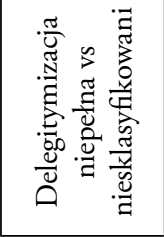 & 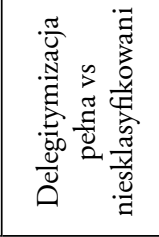 \\
\hline
\end{tabular}




\begin{tabular}{|c|c|c|c|c|c|c|c|c|c|c|c|c|c|c|c|c|c|c|c|c|}
\hline \multirow{2}{*}{ 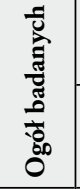 } & $a^{0}$ & $\begin{array}{l}\infty \\
\infty\end{array}$ & $\cong$ & 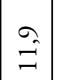 & $\begin{array}{c}\infty \\
\hat{n}\end{array}$ & $\stackrel{n}{\tilde{n}}$ & $\begin{array}{l}0 \\
\dot{8}\end{array}$ & \multirow[b]{2}{*}{ 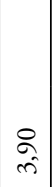 } & \multirow[b]{2}{*}{$\begin{array}{l}\infty \\
\Rightarrow \\
\Rightarrow\end{array}$} & $\approx$ & $\hat{\sigma}^{\circ}$ & $\stackrel{n}{n}$ & $\begin{array}{c}\tilde{n} \\
\tilde{n}\end{array}$ & $\begin{array}{l}0 \\
0 \\
0\end{array}$ & $\vec{a}$ & $\vec{I}$ & $\begin{array}{l}0 \\
\dot{0}\end{array}$ & \multirow[b]{2}{*}{$\begin{array}{l}\stackrel{0}{\sigma} \\
\forall\end{array}$} & \multirow[b]{2}{*}{$\begin{array}{l}\curvearrowright \\
\stackrel{2}{2}\end{array}$} & \multirow{2}{*}{ 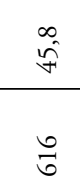 } \\
\hline & $\mathbf{z}$ & $\delta$ & $\widehat{\cong}$ & $\stackrel{\circ}{\vec{\sim}}$ & $\begin{array}{l}\infty \\
\stackrel{0}{0}\end{array}$ & $\widetilde{\widetilde{\sigma}}$ & \begin{tabular}{l}
\multirow{2}{0}{} \\
$\beth$
\end{tabular} & & & $\stackrel{\vec{m}}{m}$ & $\vec{\beth}$ & $\approx$ & $\stackrel{\infty}{\wedge}$ & $\stackrel{\infty}{-}$ & $\underset{\sigma}{+}$ & 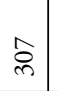 & $\stackrel{\searrow}{\bumpeq}$ & & & \\
\hline \multirow{2}{*}{ 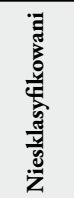 } & $0^{0}$ & $\stackrel{0}{-}$ & $\stackrel{G}{*}$ & $\begin{array}{l}\infty \\
\infty \\
\infty\end{array}$ & 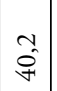 & \begin{tabular}{l}
$*$ \\
\multirow{*}{*}{}
\end{tabular} & $\begin{array}{l}0 \\
\dot{8}\end{array}$ & \multirow[b]{2}{*}{$\begin{array}{l}\stackrel{\sim}{f} \\
\underset{f}{f}\end{array}$} & \multirow[b]{2}{*}{$\begin{array}{l}\hat{\sigma} \\
\infty \\
0\end{array}$} & $\begin{array}{l}\tilde{\imath} \\
\tilde{v}\end{array}$ & $\overbrace{}^{n}$ & 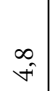 & $\begin{array}{l}0 \\
\hat{v}\end{array}$ & $\tilde{\sigma}$ & $\approx$ & $\overrightarrow{\mathrm{d}}$ & $\begin{array}{l}0 \\
\dot{0} \\
0\end{array}$ & \multirow[b]{2}{*}{$\stackrel{\vec{n}}{\vec{n}}$} & \multirow[b]{2}{*}{$\begin{array}{l}\text { ה̃ } \\
\text { iv }\end{array}$} & $\begin{array}{l}\infty \\
\stackrel{\infty}{n}\end{array}$ \\
\hline & z & 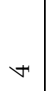 & 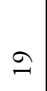 & $\stackrel{n}{n}$ & $\tilde{\sigma}$ & $\stackrel{\triangleright}{\circledR}$ & $\stackrel{\odot}{\underset{\forall}{*}}$ & & & $\stackrel{n}{\varrho}$ & $\stackrel{\sim}{\sim}$ & ㄱ. & $\cong$ & $\hat{\imath}$ & $\vec{n}$ & $\approx$ & $\begin{array}{l}\circlearrowright \\
\vec{\forall}\end{array}$ & & & $\stackrel{\infty}{\infty}$ \\
\hline \multirow{2}{*}{ 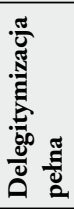 } & o & $\begin{array}{l}0 \\
0\end{array}$ & : & $\approx$ & $\begin{array}{l}\tilde{q} \\
\tilde{f}\end{array}$ & $\begin{array}{l}0 \\
\dot{n} \\
\ddot{n}^{2}\end{array}$ & $\begin{array}{l}0 \\
8 \\
8\end{array}$ & \multirow[b]{2}{*}{ 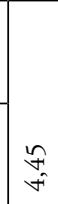 } & \multirow[b]{2}{*}{$\begin{array}{l}n \\
\tilde{B} \\
0 \\
0\end{array}$} & $\begin{array}{l}\text { nે } \\
\vec{\nu}\end{array}$ & $\hat{\tilde{0}}$ & 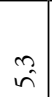 & $\overrightarrow{\vec{v}}$ & $\begin{array}{l}\infty \\
\end{array}$ & $\approx$ & $\tilde{\tilde{0}}$ & $\stackrel{0}{8}$ & \multirow[b]{2}{*}{$\overrightarrow{\widehat{n}}$} & \multirow[b]{2}{*}{$\begin{array}{l}\overrightarrow{0} \\
\stackrel{1}{c}\end{array}$} & 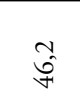 \\
\hline & z & 0 & 0 & - & $\stackrel{-}{-}$ & $=$ & $\approx$ & & & $n$ & $N$ & - & 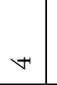 & $n$ & $\sim$ & $\sim$ & $\beth$ & & & $\bullet$ \\
\hline \multirow{2}{*}{ 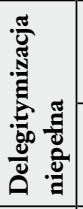 } & o & $\begin{array}{l}0 \\
0\end{array}$ & $\begin{array}{l}0 \\
0\end{array}$ & $\begin{array}{l}0 \\
0\end{array}$ & $\begin{array}{c}m \\
\stackrel{n}{n}\end{array}$ & $\hat{\delta}$ & $\begin{array}{l}0 \\
8 \\
0\end{array}$ & \multirow[b]{2}{*}{ 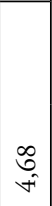 } & \multirow[b]{2}{*}{$\begin{array}{c}m \\
\stackrel{\sigma}{+} \\
0\end{array}$} & $\stackrel{+}{\stackrel{+}{*}}$ & $\begin{array}{l}0 \\
0\end{array}$ & $\begin{array}{c}\hat{ה} \\
\hat{\sim}\end{array}$ & 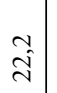 & $\stackrel{0}{0}$ & $\because$ & $\Rightarrow$ & $\stackrel{0}{8}$ & \multirow[b]{2}{*}{ 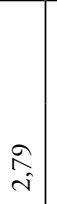 } & \multirow[b]{2}{*}{$\begin{array}{l}n \\
\hat{o} \\
i\end{array}$} & $\hat{\theta}$ \\
\hline & z & 0 & 0 & 0 & $n$ & $\bullet$ & $a$ & & & $\checkmark$ & 0 & $\sim$ & $\sim$ & 0 & 0 & - & $a$ & & & $\forall$ \\
\hline \multirow{2}{*}{ 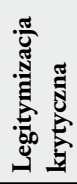 } & 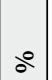 & $\stackrel{\circ}{i}$ & $\begin{array}{l}\infty \\
i\end{array}$ & $\approx$ & $\overrightarrow{\hat{q}^{+}}$ & $\tilde{\mathrm{f}}$ & $\begin{array}{l}0 \\
\dot{0} \\
0\end{array}$ & \multirow[b]{2}{*}{$\begin{array}{l}\cong \\
\underset{\forall}{*}\end{array}$} & \multirow[b]{2}{*}{$\begin{array}{l}0 \\
\tilde{a} \\
o\end{array}$} & $\underset{\varpi}{ \pm}$ & $\curvearrowright$ & 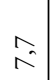 & $\stackrel{+}{m}$ & $\begin{array}{l}0 \\
=\end{array}$ & $\begin{array}{l}0 \\
\infty\end{array}$ & $\hat{\sigma}$ & $\begin{array}{l}0 \\
\dot{0}\end{array}$ & \multirow[b]{2}{*}{$\begin{array}{l}\stackrel{\sim}{*} \\
\forall\end{array}$} & \multirow[b]{2}{*}{$\stackrel{0}{\vec{\sigma}}$} & $\vec{n}$ \\
\hline & z & 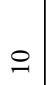 & ন & $\stackrel{F}{*}$ & Ә & $\bar{\nabla}$ & 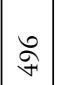 & & & $\stackrel{N}{N}$ & 아 & $\hat{m}$ & 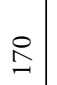 & $\stackrel{\imath}{n}$ & $\underset{F}{\sharp}$ & 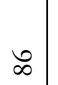 & ò & & & $\stackrel{ }{\curvearrowleft}$ \\
\hline \multirow{2}{*}{ 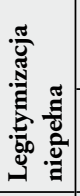 } & $0^{\circ}$ & $\begin{array}{l}+ \\
\dot{m}\end{array}$ & $\stackrel{\mathbb{J}}{\mathrm{J}}$ & $\vec{n}$ & $\begin{array}{l}0 \\
\infty \\
\infty \\
\infty\end{array}$ & $\vec{m}$ & $\begin{array}{l}0 \\
\dot{8}\end{array}$ & \multirow[b]{2}{*}{$\begin{array}{l}\vec{\infty} \\
\hat{n}\end{array}$} & \multirow[b]{2}{*}{$\begin{array}{l}\stackrel{a}{\circ} \\
\Rightarrow\end{array}$} & $\stackrel{n}{n}^{2}$ & $\stackrel{r}{n}$ & $\overrightarrow{0}$ & $\begin{array}{l}0 \\
\text { in } \\
\text { nen }\end{array}$ & $\tilde{n}$ & $\stackrel{0}{0}$ & $\stackrel{n}{\hat{n}}$ & $\begin{array}{l}0 \\
\dot{8}\end{array}$ & \multirow[b]{2}{*}{$\underset{f}{\Delta t}$} & \multirow[b]{2}{*}{$\begin{array}{l}\stackrel{0}{2} \\
\infty \\
\stackrel{-}{-}\end{array}$} & $\overrightarrow{\hat{\infty}}$ \\
\hline & z & $\stackrel{n}{\simeq}$ & $\stackrel{*}{n}$ & ৫্ర & ৫્త & 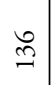 & $\underset{\sim}{\sigma}$ & & & 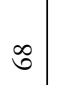 & $\stackrel{\star}{\sim}$ & 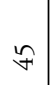 & $\stackrel{8}{-}$ & 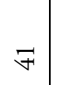 & †े & 8 & $\underset{f}{\stackrel{f}{*}}$ & & & $\stackrel{\infty}{\stackrel{\infty}{\beth}}$ \\
\hline$\frac{\pi}{3}$ & $\partial^{0}$ & $\hat{\sigma}$ & 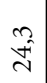 & $\stackrel{n}{\sim}$ & $\begin{array}{l}\hat{i} \\
\hat{n}\end{array}$ & $\hat{\infty}$ & $\stackrel{0}{8}$ & & & $\begin{array}{l}0 \\
\pm \\
\mathbb{t}\end{array}$ & $\stackrel{n}{\sim}$ & $\hat{\sigma}^{n}$ & $\frac{\vec{m}}{m}$ & $\stackrel{m}{\stackrel{m}{n}}$ & $\overrightarrow{0}$ & $\begin{array}{l}0 \\
\stackrel{0}{0}\end{array}$ & $\begin{array}{l}0 \\
\dot{8}\end{array}$ & & & 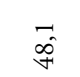 \\
\hline 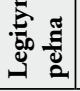 & z & $\stackrel{\infty}{m}$ & $\approx$ & ৪্) & $\stackrel{\simeq}{\beth}$ & $\stackrel{n}{\wedge}$ & $\overline{\grave{m}}$ & $\begin{array}{l}\stackrel{n}{n} \\
\tilde{n}\end{array}$ & $\begin{array}{l}\overrightarrow{0} \\
\stackrel{\sim}{=}\end{array}$ & $\stackrel{\infty}{\curvearrowleft}$ & নे & $\approx$ & $\widehat{\Xi}$ & $\approx$ & 아 & Ъ্ర & $\stackrel{\text { m }}{2}$ & $\stackrel{\vartheta}{\approx}$ & $\stackrel{n}{\approx}$ & $\tilde{n}$ \\
\hline 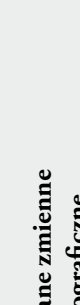 & & 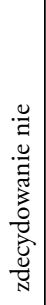 & 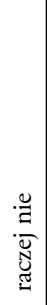 & 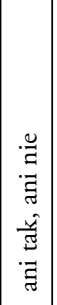 & 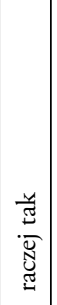 & 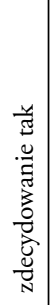 & 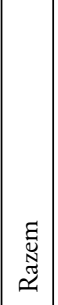 & 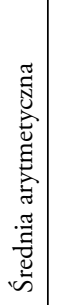 & 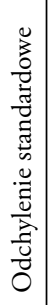 & 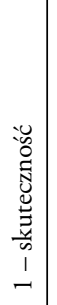 & $\sim$ & $n$ & 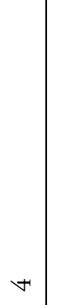 & $n$ & ๑ & 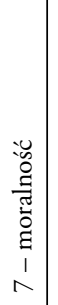 & 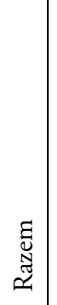 & 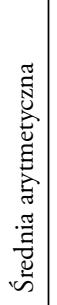 & 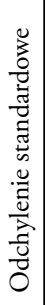 & 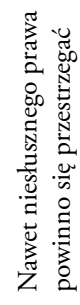 \\
\hline 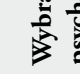 & & & & 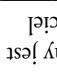 & 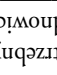 & $\begin{array}{l}\text { po Ku } \\
\text { tod } 2\end{array}$ & & & & & & & 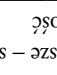 & 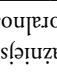 & & o & $\mu$ ] & 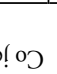 & & $\begin{array}{c}\cdots \mathrm{pu} \\
\mathrm{pe}^{8} \mathrm{O}_{\mathrm{d}}\end{array}$ \\
\hline
\end{tabular}




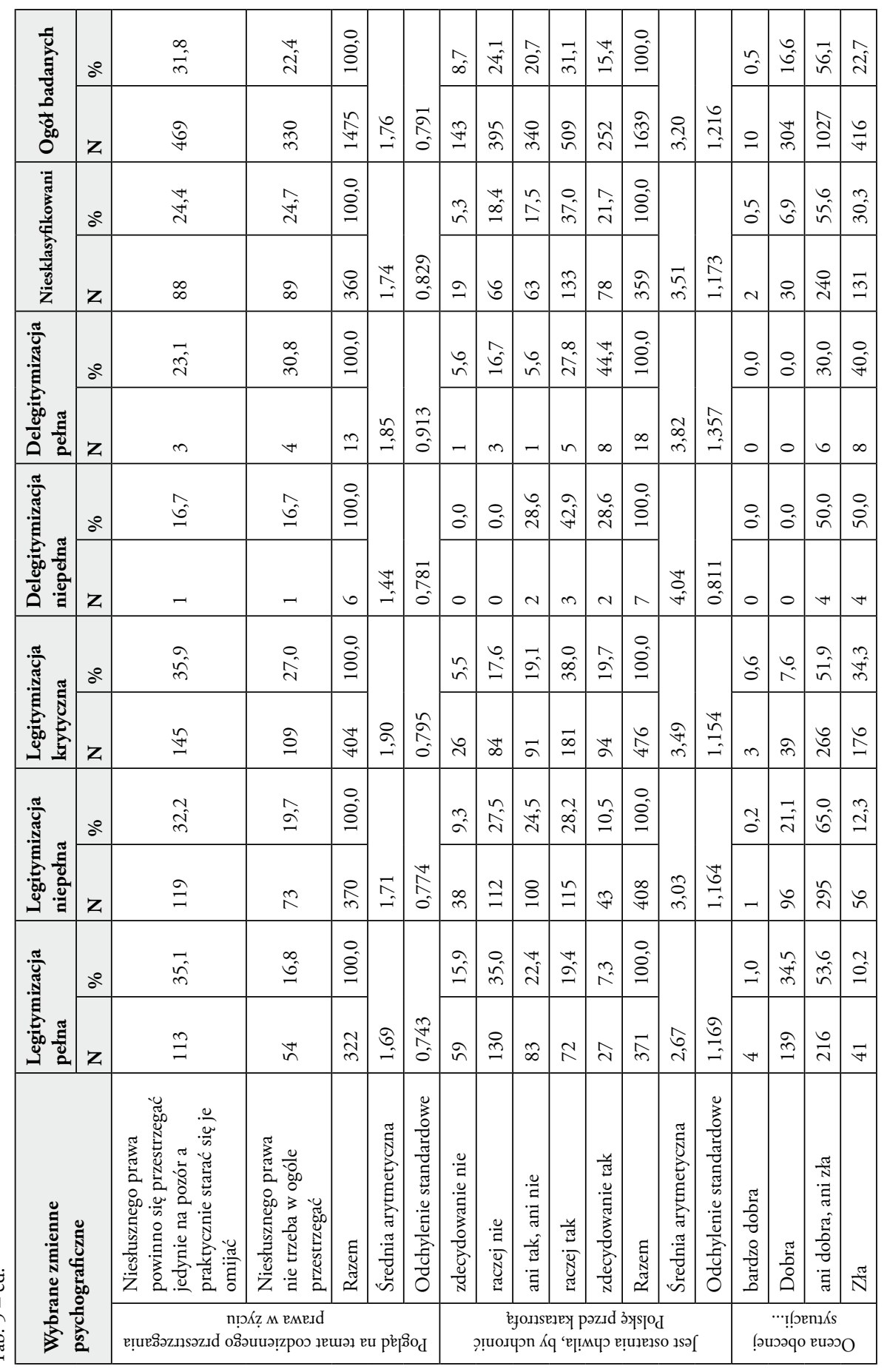




\begin{tabular}{|c|c|c|c|c|c|c|c|c|c|c|c|c|c|c|c|c|c|c|c|c|c|}
\hline \multirow{2}{*}{ 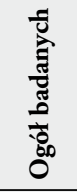 } & $\partial^{0}$ & $\stackrel{\circ}{\circ}$ & $\begin{array}{l}0 \\
\dot{8} \\
0\end{array}$ & & & $\tilde{0}$ & $\begin{array}{c}m^{2} \\
\infty^{-1} \\
\rightarrow\end{array}$ & $\vec{i}$ & $\begin{array}{l}0 \\
\hat{\imath}\end{array}$ & $\begin{array}{l}n \\
m \\
m\end{array}$ & $\begin{array}{l}0 \\
\dot{8}\end{array}$ & \multirow[b]{2}{*}{$\frac{n}{n}$} & \multirow[b]{2}{*}{$\begin{array}{l}\mathrm{N} \\
\hat{\mathrm{O}} \\
\hat{O}\end{array}$} & $\stackrel{\circ}{\forall}$ & $\stackrel{\sim}{\approx}$ & $\stackrel{\sim}{\vec{N}}$ & $\stackrel{\circ}{\dot{n}}$ & $\stackrel{\vec{\sim}}{\vec{\sim}}$ & $\begin{array}{l}0 \\
\dot{8} \\
\stackrel{0}{0}\end{array}$ & \multirow[b]{2}{*}{$\begin{array}{l}\hat{\tilde{n}} \\
\hat{n}\end{array}$} & \multirow[b]{2}{*}{$\hat{\sigma}_{\hat{\sigma}}^{n}$} \\
\hline & Z & $\curvearrowright$ & $\begin{array}{l}0 \\
\infty \\
\infty \\
=\end{array}$ & $\frac{m}{m}$ & $\begin{array}{l}\vec{v} \\
\stackrel{+}{1} \\
\vdots \\
0\end{array}$ & $a$ & $\begin{array}{l}0 \\
m \\
m\end{array}$ & $\widetilde{\Omega}$ & î & 6 & $\begin{array}{c}\underset{\text { }}{\infty} \\
\rightarrow\end{array}$ & & & ث艹 & $\widetilde{\sim}$ & $\hat{\tilde{m}}$ & $\underset{్}{\mathbb{V}}$ & 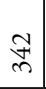 & $\overrightarrow{0}$ & & \\
\hline \multirow{2}{*}{ 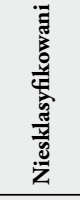 } & $\partial^{0}$ & $\hat{\sigma}^{-}$ & $\begin{array}{l}0 \\
8 \\
0\end{array}$ & & & है & $\begin{array}{l}\infty \\
\sigma^{\prime}\end{array}$ & $\begin{array}{c}n \\
\infty \\
\infty \\
+\end{array}$ & $\approx$ & $v_{0}^{+}$ & $\begin{array}{l}0 \\
\stackrel{0}{0} \\
\stackrel{0}{1}\end{array}$ & & & $\stackrel{\star}{\rightarrow}$ & $\vec{\infty}$ & 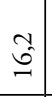 & $\begin{array}{l}\infty \\
\stackrel{\infty}{+}\end{array}$ & $\stackrel{\vec{r}}{\hat{n}}$ & $\begin{array}{l}0 \\
\dot{8} \\
0\end{array}$ & \multirow[b]{2}{*}{$\mid \begin{array}{l}\vec{\sigma} \\
\hat{n}\end{array}$} & \multirow[b]{2}{*}{$\begin{array}{l}\infty \\
\tilde{\alpha} \\
\hat{\sigma}\end{array}$} \\
\hline & $\mathbf{Z}$ & ৯े & $\underset{\widetilde{F}}{\widetilde{F}}$ & $\begin{array}{l}0 \\
n \\
m\end{array} \mid$ & $\begin{array}{l}\hat{\widehat{N}} \\
\hat{0}\end{array}$ & - & $\mathscr{F}$ & $\vec{\nabla}$ & $\approx$ & $\stackrel{\infty}{\sim}$ & $\stackrel{\infty}{\stackrel{\infty}{+}}$ & $\begin{array}{l}\infty \\
m \\
m \\
m\end{array}$ & $\begin{array}{l}\stackrel{0}{K} \\
\stackrel{n}{0} \\
\end{array}$ & $n$ & $\stackrel{\infty}{\sim}$ & 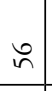 & $\sqrt{n}$ & $\stackrel{n}{\varrho}$ & $\stackrel{n}{m}$ & & \\
\hline \multirow{2}{*}{ 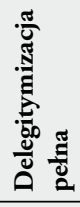 } & $\partial^{0}$ & $\begin{array}{l}0 \\
\dot{n} \\
\dot{n}\end{array}$ & $\stackrel{0}{8}$ & & & $\stackrel{0}{0}$ & $\begin{array}{l}\infty \\
\star \\
\forall\end{array}$ & $\begin{array}{l}\infty \\
\sim \\
\sim\end{array}$ & $\vec{n}$ & $\begin{array}{l}n \\
\pm \\
-1\end{array}$ & $\begin{array}{l}0 \\
\dot{8}\end{array}$ & & & O. & $\stackrel{0}{0}$ & $\begin{array}{l}0 \\
i n\end{array}$ & in & $\begin{array}{l}\stackrel{0}{n} \\
\stackrel{n}{n}\end{array}$ & $\begin{array}{l}0 \\
8 \\
0\end{array}$ & \multirow[b]{2}{*}{ 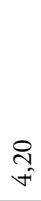 } & \multirow[b]{2}{*}{$\begin{array}{l}\text { के } \\
\stackrel{0}{0}\end{array}$} \\
\hline & $\mathbf{Z}$ & $\bullet$ & 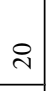 & ळे & $\begin{array}{l}2 \\
\infty \\
\hat{0} \\
0\end{array}$ & 0 & - & $n$ & $\approx$ & $n$ & $\vec{\sim}$ & $\begin{array}{l}\infty \\
\infty \\
\sim\end{array}$ & \begin{tabular}{|l}
$\stackrel{R}{R}$ \\
$\hat{2}$ \\
0
\end{tabular} & 0 & $N$ & $\neg$ & $\wedge$ & $\stackrel{0}{=}$ & $\stackrel{\mathrm{N}}{\mathrm{s}}$ & & \\
\hline \multirow{2}{*}{ 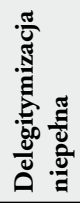 } & $0^{\circ}$ & $\begin{array}{l}0 \\
0\end{array}$ & $\begin{array}{l}0 \\
\stackrel{8}{8}\end{array}$ & & & $\begin{array}{l}0 \\
0\end{array}$ & $\hat{\imath}$ & $\tilde{n}$ & $\tilde{n}$ & $\hat{\imath}$ & $\begin{array}{l}0 \\
\stackrel{0}{0}\end{array}$ & & & $\stackrel{0}{\stackrel{\text { in }}{0}}$ & 0 & $\begin{array}{l}0 \\
\dot{\hat{N}}\end{array}$ & $\begin{array}{l}0 \\
\stackrel{i}{1}\end{array}$ & $\begin{array}{l}0 \\
\stackrel{+}{+}\end{array}$ & $\stackrel{0}{8}$ & \multirow[b]{2}{*}{$\begin{array}{l}\hat{\sigma} \\
\tilde{n}\end{array}$} & \multirow[b]{2}{*}{ స్రీ } \\
\hline & $\mathbf{Z}$ & 0 & $\infty$ & $\begin{array}{l}\approx \\
\approx \\
m\end{array}$ & $\begin{array}{l}\vec{n} \\
\tilde{0} \\
\tilde{0}\end{array}$ & 0 & - & $n$ & $n$ & - & $\infty$ & $\begin{array}{l}\hat{n} \\
\hat{n}\end{array}$ & $\begin{array}{l}\tilde{f} \\
\tilde{\sigma} \\
\hat{0}\end{array}$ & - & 0 & - & - & $\sim$ & $n$ & & \\
\hline \multirow{2}{*}{ 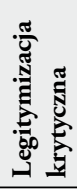 } & $\partial^{\circ}$ & $\hat{n}$ & $\begin{array}{l}0 \\
\stackrel{8}{8}\end{array}$ & & & $\begin{array}{l}0 \\
0\end{array}$ & $\mathcal{\infty}^{1}$ & $\begin{array}{l}0 \\
\text { की } \\
\forall++\end{array}$ & $\begin{array}{l}m \\
\infty \\
n^{2}\end{array}$ & 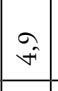 & $\stackrel{0}{0}$ & & & $\stackrel{\forall}{*}$ & $\stackrel{m}{0}$ & $\approx$ & $\hat{\vec{\forall}}$ & $\begin{array}{l}0 \\
0 \\
0 \\
i^{2}\end{array}$ & $\stackrel{0}{8}$ & \multirow[b]{2}{*}{$\begin{array}{l}\bumpeq \\
m \\
n\end{array}$} & \multirow[b]{2}{*}{$\stackrel{\stackrel{\rho}{\circ}}{\stackrel{0}{=}}$} \\
\hline & Z & సे & $\stackrel{m}{n}$ & $\hat{n}^{2}$ & 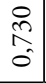 & $n$ & $\underset{F}{ }$ & 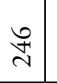 & $\precsim$ & $\stackrel{2}{\imath}$ & $\stackrel{\sim}{\approx}$ & $\begin{array}{c}\hat{m} \\
\text { n}\end{array}$ & $\left|\begin{array}{l}\bar{n} \\
\tilde{o}\end{array}\right|$ & ิㅗㄱ & के & $\infty$ & $\approx$ & 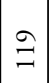 & 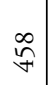 & & \\
\hline \multirow{2}{*}{ 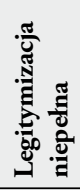 } & $0^{\circ}$ & $\stackrel{2}{-}$ & $\stackrel{0}{8}$ & & & $\hat{0}$ & 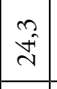 & $\begin{array}{l}0 \\
\hat{n} \\
\hat{n}\end{array}$ & $\hat{\tilde{\nu}}$ & $\Rightarrow$ & $\begin{array}{l}0 \\
\stackrel{0}{0} \\
\stackrel{0}{1}\end{array}$ & & & $\hat{n}$ & 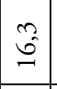 & $\hat{\varkappa}$ & $\stackrel{\circ}{\dot{m}}$ & $\stackrel{n}{n}$ & Oे & \multirow[b]{2}{*}{$\begin{array}{l}\stackrel{f}{f} \\
\hat{n}\end{array}$} & \multirow[b]{2}{*}{$\stackrel{\substack{0 \\
0}}{=}$} \\
\hline & $\mathbf{z}$ & $\bullet$ & 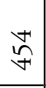 & $\stackrel{\varkappa}{\hat{i}}$ & $\begin{array}{l}\stackrel{\sim}{1} \\
0 \\
0\end{array}$ & $n$ & $\cong$ & $\underset{\sim}{\stackrel{*}{\sim}}$ & そ & in & \& & $\hat{\hat{\imath}}$ & $\begin{array}{l}\stackrel{n}{\hat{N}} \\
\hat{0}\end{array}$ & $\Xi$ & ৫ & $\hat{0}$ & $\stackrel{\infty}{\simeq}$ & $\widetilde{\sigma}$ & 拿 & & \\
\hline \multirow{2}{*}{ 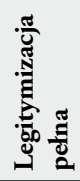 } & $a^{0}$ & $\hat{0}$ & $\stackrel{0}{8}$ & & & $\tilde{0}$ & $\begin{array}{c}m \\
\tilde{n}^{\prime}\end{array}$ & $\stackrel{m}{\approx}$ & $\stackrel{m}{=}$ & $\left|\begin{array}{l}\infty \\
0 \\
0\end{array}\right|$ & $\stackrel{0}{8}$ & & & $\tilde{6}$ & $\underset{\sim}{\stackrel{\sim}{\sim}}$ & $\overrightarrow{\mathrm{v}^{\circ}}$ & $\frac{m}{m}$ & $\begin{array}{c}0 \\
\mathfrak{I}\end{array}$ & $\ddot{8}$ & & \\
\hline & $\mathbf{z}$ & $n$ & 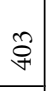 & $\begin{array}{l}\Re \\
\hat{i}\end{array}$ & $\begin{array}{l}\mathbb{2} \\
\mathbf{S} \\
0\end{array}$ & $\sim$ & $\hat{n}$ & $\stackrel{m}{\sim}$ & $\stackrel{n}{F}$ & $n$ & \& & $\begin{array}{l}\infty \\
\hat{i} \\
\hat{v}\end{array}$ & $\begin{array}{l}\frac{N}{6} \\
0 \\
0\end{array}$ & $\stackrel{\sim}{\sim}$ & $\infty$ & $\curvearrowleft$ & $\cong$ & $\mathbb{F}$ & $\begin{array}{l}\infty \\
0 \\
0\end{array}$ & $\begin{array}{l}\infty \\
\dot{m}\end{array}$ & 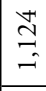 \\
\hline \multirow{2}{*}{\multicolumn{2}{|c|}{ 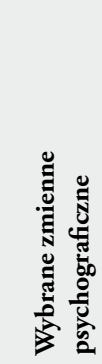 }} & 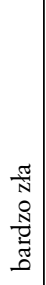 & 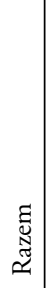 & 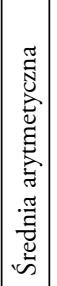 & 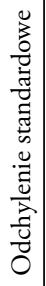 & 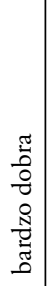 & $\begin{array}{l}\frac{\pi}{4} \\
\frac{\tilde{0}}{0} \\
9\end{array}$ & 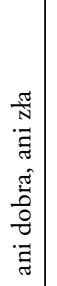 & $\frac{\pi}{N}$ & 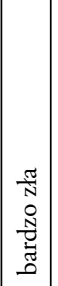 & 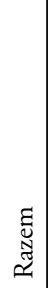 & 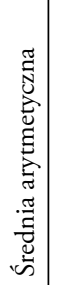 & 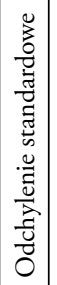 & 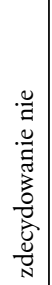 & 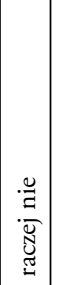 & 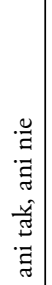 & 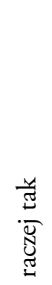 & 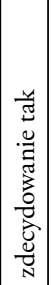 & 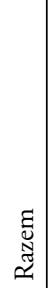 & 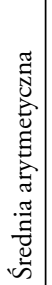 & 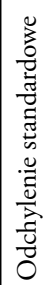 \\
\hline & & \multicolumn{4}{|c|}{ 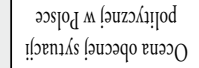 } & \multicolumn{8}{|c|}{ 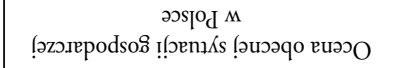 } & \multicolumn{8}{|c|}{ 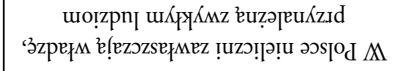 } \\
\hline
\end{tabular}




\subsection{Legitymizujący w pełni system polityczny}

Legitymizujący w pełni system polityczny stanowią piątą część zbadanej populacji dorosłych Polaków $(21,2)$. Jest to, warto podkreślić, grupa stanowiąca czynnik stabilizujący, utrwalający i rozwijający system demokratyczny, stąd jej charakterystyki socjodemograficzne i psychograficzne mają kluczowy charakter. Płeć stanowi czynnik umiarkowanie różnicujący poszczególne typy legitymizacji. W tej grupie nadreprezentowani są mężczyźni (54,7\% versus $47,3 \%$ dla ogółu badanych). Grupa ta jednak nie różni się pod względem proporcji płci od legitymizujących system polityczny nie w pełni, legitymizujących system polityczny „krytycznie”, różni się natomiast istotnie od niesklasyfikowanych oraz od delegitymizujących (w pełni i nie w pełni) system polityczny (choć tu liczebności są zbyt małe, by móc wyciągać statystycznie istotne wnioski). Zmienna „wiek” stanowi czynnik umiarkowanie odróżniający reprezentantów postawy legitymizacji pełnej od pozostałych typów postaw. Rozkłady proporcji wieku w ramach legitymizacji pełnej są tożsame z rozkładami legitymizacji niepełnej oraz krytycznej, zaś w porównaniu z innymi typami postaw - różne. $\mathrm{O}$ istocie różnicy stanowi niewielka nadreprezentacja średniego pokolenia w stosunku do rozkładów wartości wyliczonych dla ogółu (odpowiednio: 44,0\% i 40,7\%). Kategoria wykształcenia silnie odróżnia legitymizację pełną od pozostałych typów postaw. Podobieństwo rozkładów zachowane jest jedynie w odniesieniu do legitymizacji niepełnej. Pośród legitymizujących w pełni system polityczny nadreprezentowane są znacznie osoby z wyższym wykształceniem (28,5\% versus $17,9 \%$ dla ogółu) oraz umiarkowanie osoby z wykształceniem średnim $(38,8 \%$ vs 34,1\%). Wśród legitymizujących w pełni system polityczny częściej niż wśród innych typów postaw obecne są takie grupy zawodowe, jak: właściciele i kadra zarządzająca, zawody twórcze i specjaliści z wyższym wykształceniem, uczniowie i studenci. Niedoreprezentowane są natomiast kategorie: bezrobotnych, pracowników administracyjno-biurowych i pracowników usług, średniego personelu technicznego, a także robotników. Zbyt małe liczebności badanych nie pozwoliły na przeprowadzenie testów istotności statystycznej w tej kategorii socjodemograficznej. Wielkość miejsca zamieszkania stanowi słaby czynnik dyferencjacji. Legitymizujący system polityczny są podobni do legitymizujących go nie w pełni oraz do grupy niesklasyfikowanych. Legitymizujący w pełni system polityczny to na ogół mieszkańcy dużych miast - powyżej 100 tysięcy mieszkańców $(38,6 \%$ w porównaniu z rozkładami dla ogółu wynoszącymi $30,2 \%)$. Niedoreprezentowani są mieszkańcy wsi oraz małych i średnich miast. Dochód gospodarstwa domowego to zmienna istotnie różnicująca poszczególne typy legitymizacji. Podobieństwo zachodzi wyłącznie pomiędzy dwoma typami 
postaw najsilniej wspierających system polityczny: legitymizacją pełną i legitymizacją niepełną. Pośród legitymizujących system polityczny przeważają osoby o wysokich dochodach (dwie najwyższe kategorie dochodu: wysoko zarabiający oraz bardzo wysoko zarabiający). Stanowią oni 35,2\% analizowanego typu legitymizacji, podczas gdy wśród ogółu badanych grupa ta liczy zaledwie 22,4\%. Orientacja ideologiczna umiarkowanie odróżnia od siebie reprezentantów poszczególnych typów legitymizacji. Legitymizujący w pełni system polityczny są podobni jedynie do ambiwalentnych wobec systemu politycznego. Wśród legitymizujących w pełni system polityczny przeważają zwolennicy prawicy (45,3\% vs 36,7\% dla ogółu). Stosunek do religii i wiary nie jest czynnikiem różnicującym poszczególne typy postaw wobec systemu politycznego. $Z$ socjodemograficznego punktu widzenia legitymizujący w pełni system polityczny stanowią grupę różną od ogółu Polaków, jak też od innych grup. Legitymizujący w pełni system polityczny charakteryzują się więc silną nadreprezentacją osób z wyższym wykształceniem i umiarkowaną nadwyżką osób z wykształceniem średnim, osób z dochodami wysokimi, a także bardzo wysokimi wykonującymi zawody takie, jak: właściciele i kadra zarządzająca, zawody twórcze i specjaliści z wyższym wykształceniem, uczniowie i studenci, zamieszkałymi w miastach powyżej 100 tysięcy mieszkańców, nieco większą niż przeciętna liczebnością średniego pokolenia oraz mężczyzn. W tej grupie przeważają zwolennicy prawicy. Nieistotną zmienną jest stosunek do religii i wiary. $\mathrm{Na}$ ogół grupa ta podobna jest pod względem parametrów socjodemograficznych do legitymizujących nie w pełni system polityczny, jak też do grupy legitymizujących ów system „krytycznie”.

Przejawiający postawy pełnej legitymizacji różnią się istotnie od pozostałych grup pod względem psychograficznym. Choć połowa z nich uważa, że Polsce potrzebny jest silny odnowiciel $(50,7 \%)$, jednakże jest to wartość najniższa w porównaniu z pozostałymi grupami oraz średnią dla całości. Zwraca uwagę największa w porównaniu z pozostałymi typami postaw dyspersja odpowiedzi na to pytanie, co świadczy o silnej polaryzacji w tej grupie. Przedstawiciele tej grupy legitymizujących w pełni system polityczny wydają się najsilniej zsocjalizowani politycznie: uznają, że w polityce ważniejsza jest moralność niż skuteczność. Wynik odpowiedzi na to pytanie nie jest jednak obiektywnie zadowalający: na siedmiopunktowej skali średnia odpowiedzi wynosi zaledwie 4,19. Zauważalne jest w tej grupie liberalne podejście do codziennego przestrzegania prawa. Przedstawiciele tej grupy w stopniu nieco większym niż przedstawiciele postawy legitymizacji niepełnej oraz legitymizacji „krytycznej” uznają, że można omijać niesłuszne prawo. Jest to najbardziej liberalna pod tym względem grupa, a uzyskane wyniki stawiają ją w jednym rzędzie z niesklasyfikowanymi, a nawet delegitymizującymi. W tej grupie poziom lęku 
przed grożącą Polsce katastrofą jest najniższy w porównaniu ze średnią, jak też pozostałymi grupami (średnia odpowiedzi dla legitymizujących w pełni wynosi 2,67, podczas gdy dla ogółu - 3,20). Również ocena obecnej sytuacji gospodarczej i politycznej w Polsce jest najbardziej optymistyczna w porównaniu z przedstawicielami pozostałych wyróżnionych typów postaw. W najmniejszym stopniu w grupie tej obecne są postawy populistyczne, istotnie mniejszy, niż w innych grupach jest odsetek odpowiedzi przychylających się do twierdzenia, że w Polsce nieliczni zawłaszczają władzę przynależną zwykłym ludziom (średnia arytmetyczna w tej grupie wynosi 3,18, zaś średnia dla ogółu - 3,59). W grupie tej w najmniejszym stopniu obecne są lęki polityczno-ekonomiczne i postawy autorytarne. Grupę tę zasadnie można określić mianem stabilizatora polskiej demokracji.

\subsection{Legitymizujący nie w pełni system polityczny}

Co czwarty z badanych dorosłych Polaków $(24,7 \%)$ nie w pełni legitymizuje system polityczny. Pomiędzy tą grupą, a ogółem oraz pozostałymi grupami z osobna odnotowujemy zarówno podobieństwa, jak też różnice. Przejawiający postawę legitymizacji niepełnej nie różnią się istotnie pod względem rozkładu płci zarówno od pozostałych grup, jak też od ogółu. Z kolei wiek stanowi istotną zmienną odróżniającą ten typ postaw od pozostałych. Szczególnie nadreprezentowane jest w tej grupie młode pokolenie ( $43,2 \%$ versus $34,1 \%$ dla ogółu). Rozkład tej zmiennej w analizowanej grupie jest istotnie różny statystycznie od obu grup delegitymizujących oraz od niesklasyfikowanych, zaś podobny do pozostałych. Wykształcenie stanowi umiarkowanie silny czynnik charakteryzujący grupę legitymizującą w niepełnym wymiarze system polityczny. Umiarkowanie nadreprezentowana jest wśród nich kategoria osób z wykształceniem wyższym $(21,8 \%$ w analizowanej grupie, a 17,9\% dla ogółu badanych), zaś nieco niedoreprezentowani są badani z wykształceniem niepełnym średnim i niższym (44,0\% vs 48,0\%). Legitymizacja niepełna wykazuje podobieństwo pod względem rozkładów brzegowych wykształcenia do legitymizacji pełnej oraz do legitymizacji krytycznej. Różni się natomiast istotnie statystycznie od pozostałych typów legitymizacji. Pod względem przynależności do grupy społeczno-zawodowej wśród legitymizujących nie w pełni system polityczny odnotowujemy nieznacznie zwiększoną w stosunku do całości populacji liczbę pracowników administracyjno-biurowych i pracowników usług, średniego personelu technicznego (20,9\% vs 15,4\%). Zauważalna jest nieco mniejsza niż w całości populacji grupa emerytów i rencistów (24,9\% vs 30,2\%). Zbyt małe liczebności w poszczególnych komórkach nie pozwoliły na stwierdze- 
nie, czy różnice te są statystycznie istotne. Reprezentanci analizowanego typu postawy pod względem wielkości miejsca zamieszkania nie różnią się od średniej dla całej populacji. Różnice pozostają w przedziale maksymalnego, standardowego błędu oszacowania. Statystycznie istotne różnice dotyczą dwóch typów postaw delegitymizacyjnych (delegitymizacji pełnej i delegitymizacji niepełnej), jednak liczebności w tych grupach są zbyt małe, by traktować te wyniki jako wiążące. Dochód gospodarstwa domowego stanowi silny czynnik dyferencjacji reprezentantów wyróżnionych typów postaw. Różnice pomiędzy wynikami dla całości populacji a analizowanym typem postaw dotyczą grupy o najniższym i grupy o najwyższym poziomie dochodów. Ta pierwsza jest niedoreprezentowana, ta druga natomiast - nadreprezentowana. Legitymizujący nie w pełni system polityczny podobni są do legitymizujących w pełni system polityczny, zaś różnią się istotnie od pozostałych typów postaw. Legitymizujący nie w pełni system polityczny to przede wszystkim zwolennicy opcji centrowej $(55,1 \% \mathrm{w}$ tej grupie, podczas gdy 46,6\% w całości badanej populacji). Niedoreprezentowane są natomiast w tej kategorii osoby o orientacji prawicowej (30,1\% vs 36,7\%). W tym zakresie legitymizujący nie w pełni system polityczny podobni są do legitymizujących system polityczny „krytycznie” oraz do grupy niesklasyfikowanych. Z kolei stosunek do wiary i religii, podobnie jak w pozostałych typach postaw, nie odróżnia poszczególnych typów legitymizacji. Grupa legitymizujących nie w pełni system polityczny posiada odmienne niż pozostałe charakterystyki socjodemograficzne, choć daje się także odnotować szereg podobieństw w szczególności do legitymizujących w pełni system oraz legitymizujących go „krytycznie”. Unikalność tej grupy przejawia się: nadreprezentacją młodego pokolenia, zwiększoną liczbą osób z wykształceniem wyższym (choć nie tak bardzo jak wśród legitymizujących w pełni system polityczny), nieznacznie podniesioną w stosunku do całości populacji liczebnością pracowników administracyjno-biurowych i pracowników usług, średniego personelu technicznego, niewielką nadreprezentacją osób bardzo wysoko zarabiających oraz znaczną liczbą osób o poglądach centrowych. Nieistotne okazują się płeć, wielkość miejsca zamieszkania oraz postawy wobec wiary i religii.

Legitymizujący nie w pełni system polityczny lokują się pod względem wybranych postaw psychograficznych pomiędzy legitymizacją pełną, a „krytyczną”, bliżej tej pierwszej. Uzyskane wyniki znajdują się po stronie odpowiedzi pozytywnych lub w granicach średniej dla ogółu. Jest to grupa, podobnie jak omawiani wcześniej legitymizujący, silnie legitymizująca polski system polityczny. Fakt zróżnicowanych strategii uczestnictwa tylko częściowo może zależeć od wadliwej socjalizacji politycznej. 


\subsection{Legitymizujący „krytycznie” system polityczny}

Legitymizujący „krytycznie” system polityczny stanowią najliczniejszą grupę wśród wyróżnionych typów (27,4\% zakwalifikowanych do tego typu). Uważają oni demokrację za system rządzenia lepszy niż inny, jednakże wyrażają swoje niezadowolenie w stosunku do jej funkcjonowania w praktyce polskiej polityki. W różnym też stopniu uczestniczą oni w konwencjonalnych formach partycypacji politycznej. Rola tej grupy w polskiej demokracji może być rozpatrywana dwojako. Po pierwsze optymistycznie możemy patrzeć na nią jako obywatelski, krytyczny czynnik kontroli nad władzami. Może być ona również postrzegana jako grupa wysoko zsocjalizowanych politycznie obywateli, wyraźniej niż inni dostrzegająca różnice pomiędzy teorią i praktyką polskiej demokracji oraz w efekcie wyrażająca swoje niezadowolenie. Pesymistyczne ujęcie każe traktować tę grupę jako malkontentów stanowiących czynnik utrudniający funkcjonowanie polskiej demokracji i potencjalnie mogących przekształcić się w delegitymizujących system polityczny. Płeć okazuje się czynnikiem nieistotnym, rozkład brzegowy zmiennej dla tego typu legitymizacji nie odbiega od rozkładu dla średniej. Różnice pomiędzy legitymizującymi krytycznie i pozostałymi typami postaw wobec legitymizacji są nieistotne statystycznie. Wiek to umiarkowany czynnik zróżnicowania. Legitymizujący „krytycznie” wykazują podobieństwo pod tym względem do następujących typów legitymizacji: pełnej i niepełnej. Różnice występują natomiast pomiędzy legitymizacją „krytyczną”, a niesklasyfikowanymi. Wśród reprezentantów postaw krytycznych wobec systemu politycznego dostrzegamy niewielką w stosunku do ogółu (44,7\% versus 40,7\%) nadreprezentację średniego pokolenia. Silnym czynnikiem dyferencjacji jest wykształcenie. Rozkład tej zmiennej upodabnia grupę nastawionych krytycznie wobec systemu politycznego do legitymizujących system polityczny nie w pełni. Legitymizacja „krytyczna” jest istotnie statystycznie odmienna od pozostałych typów postaw. Grupę tę charakteryzuje niewielka nadwyżka osób z wykształceniem średnim, pomaturalnym, policealnym i niepełnym wyższym (37,2\% vs 34\% dla ogółu badanych). Rozkłady brzegowe przynależności do grupy społeczno-zawodowej są tożsame dla całości badanej populacji. Również wielkość miejsca zamieszkania mieści się w graniach wyników dla ogółu. Z kolei dochód gospodarstwa domowego świadczy o odmienności tego typu legitymizacji od pozostałych. Dostrzegamy nieznaczne niedoreprezentowanie osób z dochodami najwyższymi (2,4\% do legitymizujących „krytycznie” w porównaniu z 5,9\% dla ogółu badanych). Orientacja ideologiczna okazuje się niezbyt silnym czynnikiem dyferencjacji. Pod tym względem legitymizacja „krytyczna” podobna jest do trzech następujących typów postaw: legitymizujących w pełni, nie 
w pełni oraz niesklasyfikowanych. Rozkłady poszczególnych wartości dla lewicy, centrum i prawicy nie odbiegają jednak od tych przyjmowanych przez rozkłady ogółu badanych. Postawa wobec religii oraz siła wiary nie stanowi czynnika różnicującego tę postawę. Reasumując, krytycznie nastawieni wobec systemu politycznego nie odbiegają zbytnio od rozkładów wartości dla ogółu. Najsilniejszym czynnikiem odróżniającym tę grupę od innych jest wykształcenie, gdzie odnotowujemy nadreprezentację osób z wykształceniem średnim, oraz dochód (dostrzegalny jest nieznaczny niedobór osób z dochodami najwyższymi). Umiarkowanym czynnikiem zróżnicowania jest wiek - tu występuje zwiększona w stosunku do typowych wartości dla całości obecność pokolenia średniego. Do czynników różnicujących zaliczymy również orientację ideologiczną. Nieistotne są takie zmienne socjopsychodemograficzne, jak: płeć, przynależność do grupy społeczno-zawodowej, wielkość miejsca zamieszkania oraz postawy wobec religii i wiary.

Reprezentanci tej grupy przejawiają umiarkowane postawy autorytarne, wskazując silniej niż w postawach legitymizacyjnych, że Polsce potrzebny jest silny odnowiciel (średnia arytmetyczna wskazań wynosi 4,15 ). Taki wynik upodabnia tę kategorię do niesklasyfikowanych oraz legitymizujących. Na uwagę zasługuje ujmowanie polityki w kategoriach w większym stopniu moralności niż skuteczności. Grupa ta uzyskała najwyższy spośród innych grup wynik pod tym względem $(4,12)$. Również najwyższy jest w tej grupie liberalizm w stosunku do litery niesłusznego prawa. Przedstawiciele tej grupy w największym stopniu negują wartość jego przestrzegania. Poziom lęku przed katastrofą i ocena sytuacji gospodarczej oraz politycznej lokuje tę grupę wśród niesklasyfikowanych, a także delegitymizujących. Podobnie rzecz ma się w odniesieniu do twierdzenia, iż władzę w Polsce zagarniają nieliczni.

\subsection{Delegitymizujący nie w pełni system polityczny}

Postawa delegitymizacji niepełnej stanowi marginalny pod względem liczebności typ legitymizacji systemu politycznego. W grupie tej znalazło się zaledwie piętnastu badanych $(0,8 \%$ ogółu respondentów). Niewielkie liczebności nie uprawniają do przeprowadzenia wnioskowania statystycznego, poniższe wnioski mają charakter jakościowy i opisowy niepretendujący do statusu prawidłowości stochastycznych. W ramach tego typu postawy skłania do refleksji nadreprezentacja: kobiet, pokolenia średniego, wykształcenia niepełnego średniego i niższego, emerytów i rencistów, mieszkańców wsi, osób o niskich i bardzo niskich dochodach, określających się jako zwolennicy centrum, wierzących. 
Natężenie zmiennych psychodemograficznych przyjmuje w grupie delegitymizujących skrajne, negatywne wartości. Ten typ postaw uzyskał jednak zbyt małe liczebności dla prawomocnego wnioskowania statystycznego.

\subsection{Delegitymizujący w pełni system polityczny}

Niewystarczające liczebności zakwalifikowanych do typu delegitymizacji pełnej powodują niemożność podjęcia wnioskowania statystycznego ergo rzutowania wyników z próby na populację. Wnioski poniższe należy traktować jako deskryptywne i obarczone bardzo dużym ryzykiem błędu. Typ postawy delegitymizujących całkowicie system polityczny reprezentuje zaledwie dwudziestu dwóch, a więc $1,1 \%$ ogółu respondentów. Dostrzegamy (nie wiedząc czy to prawidłowość statystyczna, czy artefakt) następujące przekraczające wyniki dla ogółu badanych wartości: przewagę mężczyzn, średniego pokolenia, osób o umiarkowanych dochodach, zwolenników lewicy, a także wierzących.

Odpowiedzi na pytania psychodemograficzne uzyskały skrajnie negatywne wskazania w porównaniu z pozostałymi grupami, choć wyniki te są statystycznie nieistotne. Niemożność ekstrapolowania wyników na ogół dorosłych Polaków wynika ze zbyt małej liczebności tej grupy.

\subsection{Próba analizy niesklasyfikowanych postaw wobec systemu politycznego}

Niesklasyfikowani stanowią grupę odmienną od pozostałych, a także wewnętrznie zróżnicowaną. Różnice dostrzegalne są w rozkładach płci. Zaznacza się wyraźnie znaczna przewaga kobiet w tej grupie ( $58,2 \%$ versus $52,7 \%$ dla ogółu). Te charakterystyki czynią ów typ postawy podobnym do postawy legitymizacji niepełnej oraz legitymizacji „krytycznej”. Wiek jest silną zmienną odróżniającą niesklasyfikowanych od pozostałych typów postaw. Znacznie i istotnie statystycznie nadreprezentowane jest w tej grupie starsze pokolenie (33,5\% vs 24,8\% dla ogółu). Również rozkłady brzegowe wykształcenia świadczą o odmienności niesklasyfikowanych od pozostałych grup, jak też od wartości przyjmowanych przez tę zmienną dla ogółu. Grupa ta odznacza się silną nadreprezentacją osób z wykształceniem najniższym: podstawowym, zawodowym i niepełnym średnim $(64,9 \%$ vs 48,0\%). Analiza przynależności do grupy społeczno-zawodowej ujawnia zwiększone w stosunku do ogółu liczebności w kategorii emerytów i rencistów, z kolei obniżone 
liczebności w grupie właścicieli i kadry zarządzającej oraz zawodów twórczych, a także specjalistów z wyższym wykształceniem. Wielkość miejsca zamieszkania badanych umiarkowanie silnie odróżnia tę grupę od pozostałych - jest ona podobna do grupy krytycznie nastawionych do systemu politycznego. Najliczniejszą grupą są tu mieszkańcy wsi (46,3\% vs 37,7\% dla ogółu respondentów). Istotnie różnią się niesklasyfikowani również pod względem dochodów netto gospodarstwa domowego. Dominują osoby o bardzo niskich i niskich dochodach. Stanowią one blisko $3 / 4$ wszystkich znajdujących się w tej grupie $(72,8 \%)$, podczas gdy wśród ogółu badanych nieco ponad połowę $(57,1 \%)$. Pod tym względem niesklasyfikowani różnią się istotnie statystycznie od pozostałych wyodrębnionych typów. Różnice pomiędzy rozkładami brzegowymi w obrębie niesklasyfikowanych, a pozostałymi typami oraz ogółem badanych są niewielkie i nieistotne pod względem statystycznym. Orientacja ideologiczna na triadycznej skali lewica-centrum-prawica umiarkowanie silnie świadczy o odrębności niesklasyfikowanych od pozostałych grup, jak też od ogółu. Odnotowujemy niewielką nadwyżkę respondentów o poglądach lewicowych. Analogiczne rozkłady odnajdujemy u przejawiających legitymizację niepełną oraz pośród krytycznie nastawionych do polskiego systemu politycznego.

Analiza wybranych zmiennych psychograficznych obecnych w zbiorze PGSW przekonuje, że niesklasyfikowani stanowią grupę krytyczną w stosunku do instytucji systemu politycznego.

Zdecydowanie bardziej popierają oni stwierdzenie, że Polsce potrzebny jest silny odnowiciel, aniżeli reprezentanci postaw legitymizujących, a nawet postawy krytycznej wobec systemu. Grupę tę charakteryzuje duża niezgodność, co do odpowiedzi na pytanie, co w polityce jest ważniejsze - skuteczność czy moralność. Średnia dla tej grupy jest porównywalna dla średniej dla ogółu, jednakże odchylenie standardowe - miara rozrzutu odpowiedzi - jest tu najwyższa wśród wszystkich grup. W grupie tej widoczne są nastroje katastroficzne - średnia dla niesklasyfikowanych wynosi 3,51, podczas gdy średnia dla ogółu -3,20. Grupa ta ocenia ponadto negatywnie sytuację gospodarczą i polityczną w Polsce. Uzyskane wyniki upodabniają ją do legitymizujących „krytycznie” system polityczny i delegitymizujących go.

W grupie tej dominuje przekonanie, że nieliczni zawłaszczają władzę przynależną zwykłym ludziom. Odpowiedzi te są mało zróżnicowane (niska wartość przyjmowana przez odchylenie standardowe) i negatywne jak odpowiedzi delegitymizujących - blisko $3 / 4$ znajdujących się w tej grupie zgadza się raczej lub zdecydowanie z tym stwierdzeniem $(74,2 \%)$.

Niesklasyfikowani nie stanowią jednolitej grupy. W ich ramach można wyróżnić szereg podgrup. Do celów segmentacyjnych można wykorzystać zmienne użyte do definiowania poszczególnych typów postaw. 
Najobszerniejszą grupę w ramach niesklasyfikowanych (152 wskazania, 7,9\% ogółu) stanowią przejawiający postawy, którym można nadać miano głębokiej legitymizacji „krytycznej”. Podobnie jak zakwalifikowani do grupy legitymizacji „krytycznej” reprezentanci tej kategorii uważają, że demokracja w Polsce funkcjonuje źle lub bardzo źle, a także przejawiają rozmaite strategie uczestnictwa: pełne, sporadyczne lub jego brak. Jednakże ich niezadowolenie jest głębsze: nie uważają oni systemu demokratycznego za lepszy niż inne (odpowiedzi 3 i 4 w PD2).

Niemal równie liczną kategorię ( 144 wskazania, 7,5\% ogółu) stanowią ci, którzy - przyjmując różne strategie uczestnictwa w polityce - są zadowoleni z funkcjonowania demokracji w Polsce, jednakże nie są w stanie udzielić odpowiedzi na pytanie, czy demokracja jest to lepszy system rządzenia niż każdy inny (odpowiedzi „trudno powiedzieć” i „odmowa podania odpowiedzi”). Nazwijmy ich prosystemowymi i dodajmy: indyferentnymi. Drugi z przymiotników ma podkreślać fakt braku skrystalizowanej postawy dotyczącej systemu politycznego. Można jednakże podejrzewać, że odpowiedzi beztreściowe są zawoalowanymi postawami negatywnymi wobec systemu. Jeśli tak, to grupa ta - wcale niemała - powinna dołączyć do legitymizujących system polityczny.

Pozostałe grupy, które można w ramach niesklasyfikowanych wyróżnić nie są już tak liczne. Są to kolejno:

- umiarkowani oponenci (charakteryzowani przez jedno wskazanie negatywne w pytaniach o wyższość demokracji nad innymi ustrojami lub na pytanie o zadowolenie z funkcjonowania demokracji w Polsce). W tej grupie odnotowujemy 62 wskazania, co stanowi 3,2\% ogółu badanych;

- odrzucający demokrację (nieuznający jej za system polityczny lepszy niż inne), jednak wyrażający zadowolenie z jej funkcjonowania. Ta, cokolwiek paradoksalna postawa, uzyskała 47 zwolenników (2,5\% ogółu);

- umiarkowanie indyferentni (definiowani przez brak postawy wobec demokracji lub funkcjonowania systemu politycznego - dopuszczalna maksymalnie jedna „nie wiem” na dowolne z dwóch wymienionych pytań). Grupa ta stanowi 2,3\% ogółu (44 wskazania);

- wyalienowani lub rytualni uczestnicy - niepotrafiący ocenić zarówno wyższości demokracji nad innymi ustrojami, ani jej funkcjonowania, jednakże intensywnie uczestniczący w życiu politycznym (brak absencji wyborczej). Kategoria ta stanowi 1,5\% ogółu (29 wskazań).

Wśród niesklasyfikowanych przeważają postawy negatywne, co lokuje tę grupę pomiędzy krytycznie nastawionymi do systemu politycznego i postawami delegitymizującymi. Ich analiza oraz precyzyjne umiejscowienie okazało się o tyle ważne, że zmienia ono dość optymistyczny rozkład odpowiedzi uzyskany po na- 
łożeniu siatki segmentacyjnej pięciu rudymentarnych typów postaw wobec systemu politycznego. Choć to grupa zróżnicowana, to jednak widoczne są w niej silne tendencje autorytarne, postawy niezadowolenia i nieufności. Potencjalnie grupa ta może stanowić czynnik destabilizacji systemu politycznego.

\section{Zakończenie. Społeczeństwo polskie - czynnik konstruktywnych zmian czy destabilizacji?}

Przede wszystkim należy podjąć refleksję nad znaczeniem uzyskanych wyników analiz. Za wartość należy poczytać fakt, że blisko połowa społeczeństwa popiera demokratyczne metanormy, a jednocześnie wyraża zadowolenie zarówno z funkcjonowania demokracji, jak i uczestniczy mniej lub bardziej aktywnie w polityce. Istnieje zatem pewien „twardy rdzeń” ludzi z klasy średniej i dobrze sytuowanych, którzy - należy przypuszczać - nie dopuszczą do destabilizacji systemu, będą go wspierać i utrwalać. Ponadto istnienie obejmującej ponad czwartą część społeczeństwa kategorii nastawionych krytycznie do systemu politycznego $(27,4 \%)$, a więc umiarkowanie go delegitymizujących nie musi świadczyć o braku konsolidacji polskiej demokracji, a wręcz przeciwnie. Zdrowy sceptycyzm w połączeniu z gotowością do podejmowania działań politycznych, odmowa pozostawiania spraw politycznych rządzącym, a jednocześnie przekonanie do wartości i zasad demokracji znacznie ułatwiają proces konsolidacji demokracji lub też świadczą o tym, że w wymiarze społecznym został on zakończony, a w wymiarze instytucjonalnym wykazuje istotne braki. Postawę krytyczną należy uznać za doskonały czynnik kontroli władzy politycznej, a jednocześnie miarę konsolidacji polskiej demokracji. Powinna natomiast niepokoić obecność grup, które negatywnie oceniają wartość demokratycznych reguł gry, względnie nie potrafią ich ocenić. Negatywną postawę prezentuje co ósmy Polak (12\%). Jeszcze większa liczba osób - bo blisko połowa deklaruje niezadowolenie $\mathrm{z}$ działania systemu politycznego w Polsce (42,3\%). Szczególnie ten ostatni wynik może świadczyć o tym, że nie zaszła jeszcze - jak to trafnie określał Blondel - autonomizacja polskiego systemu politycznego (Blondel, 1976). Zjawisko to polega na tym, że wraz z upływem czasu dany demokratyczny system polityczny zaczyna być traktowany przez ogół społeczeństwa jako naturalny. Jednakże ów potencjał niezadowolenia ma - jak wskazywano wyżej - podłoże ekonomiczne, co wydaje się cząstkowo potwierdzać hipotezę szkoły pozytywistyczno-systemowej (1976), a ma charakter niestety względnie nieusuwalny.

Istotnym wątkiem każdego zakończenia jest wskazanie potrzeby i kierunków dalszych badań. Zaprojektowana na potrzeby niniejszego artykułu typolo- 
gia może posłużyć do oceny postępów konsolidacji polskiej demokracji. Nadaje się ona do zastosowania zarówno dla źródeł wtórnych, jak też pierwotnych. W tym ostatnim przypadku należałoby jednak zastanowić się nad wprowadzeniem dedykowanych zmiennych (najlepiej łączonych w skale lub indeksy), które bardziej adekwatnie pozwoliłyby mierzyć poziom legitymizacji. Równie ważne byłoby przekonanie się, w jaki sposób ludzie proliferują pomiędzy poszczególnymi typami legitymizacji, a więc na ile ich postawy są trwałe oraz jakie czynniki sprawiają, że dają oni lub wycofują legitymizację wobec systemu politycznego. Równie istotne wydaje się odkrycie, w jakim stopniu wyszczególnione postawy mają charakter nawykowy i bezrefleksyjny, a w jakim stopniu są one wynikiem świadomej, aktualnej i systematycznie aktualizowanej refleksji.

\section{Bibliografia:}

Agh, A. (1998). The Politics of Central Europe. Londyn: SAGE Publications Ltd.

Almond, G.A., Verba S. (1965). The Civic Culture. Political Attitudes and Democracy in Five Nations. Boston: Little, Brown and Company.

Antoszewski, A. (2000). Konsolidacja demokracji jako przedmiot zainteresowań współczesnej politologii. W: Politologia wroctawska. Ksiega jubileuszowa z okazji 30-lecia Instytutu Politologii Uniwersytetu Wrocławskiego (s. 53-65). Wrocław: Wydawnictwo Uniwersytetu Wrocławskiego.

Antoszewski, A. (2006). Systemy polityczne Europy Środkowej i Wschodniej. Wrocław: Wydawnictwo Uniwersytetu Wrocławskiego.

Blondel, J. (1976). Thinking Politically. Londyn: Wildwood House Ltd.

Błuszkowski, J., Mider, D. (2012). Demokracja późnej nowoczesności. Warszawa: Dom Wydawniczy ELIPSA.

Bronowicka, A. (2007). Alienacja polityczna i poczucie zagrożenia a dynamika akceptacji rządów silnej ręki w okresie transformacji systemowej. W: J. Klebaniuk (red.), Fenomen nierówności spotecznych. Nierówności spoteczne w refleksji humanistycznej (s. 397-419). Warszawa: ENETEIA Wydawnictwo Psychologii i Kultury.

Cochran, W.G. (1952). The $\mathrm{x}^{2}$ Test of Goodness of Fit. The Annals of Mathematical Statistics, vol. 23, 315-345.

Dahl, R.A. (1995). Demokracja i jej krytycy. Kraków: Znak.

Dahl, R.A. (2000). O demokracji. Kraków: Znak.

Dawisha, K., Parrot B. (1998). The Consolidation of Democracy in East-Central Europe. Cambridge: Cambridge Univesity Press.

Diamond, L. (1999). Developing Democracy. Toward Consolidation. Baltimore: The Johns Hopkins University Press.

Finifter, A.W. (1970). Dimensions of Political Alienation. The American Political Science Review, vol. 64, 389-410. 
Garlicki, J. (2014) (red.), Legitymizacja transformacji i systemu politycznego w Polsce, Warszawa: Dom Wydawniczy Elipsa.

Grzeszczak, A. (1995). Konsolidacja demokracji: aspekty teoretyczne i praktyczne. Ad Meritum, t. 2(I).

Gwiazda, A. (2001). Paradoks demokracji. Przeglad Politologiczny, t. 1-2.

Jellinek, G. (1892). Eine Naturlehre des Staates. W: W. Roscher, Politik, geschichtliche Naturlehre der Monarchie, Aristokratie und Demokratie. Stuttgart: Gotha.

Kaase, M., Barnes, S.H. (1979). In Conclusion. The Future of Political Protest in Western Democracies. W: S.H. Barnes, M. Kaase (red.), Political Action. Mass Participation in Five Western Democracies (s. 523-536). Beverly Hills: CA Sage.

Kabashima, I., Marshall, J., Uekami, T., Hyun, D.S. (2000). Casual Cynics or Disillusioned Democrats? Political Alienation in Japan. Political Psychology, 21(4), 779-804.

Kolarska-Bobińska, L. (2008). Konsolidacja demokracji w Europie Środkowej i Wschodniej po rozszerzeniu Unii Europejskiej. W: U. Kurczewska (red.), Deficyt demokracji w Unii Europejskiej a europejskie grupy interesów. Warszawa: Wydawnictwo Uniwersytetu Warszawskiego.

Konsolidacja. W: Słownik wyrazów obcych i zwrotów obcojęzycznych Władysława Kopalinskiego. Pobrane z: http://www.slownikonline.pl/kopalinski/4E83A32B6E4A0A45C12565E90048922A.php.

Konsolidacja. W: Uniwersalny Stownik Jezyka Polskiego PWN. Pobrane z: http://usjp.pwn. pl/lista.php?co=konsolidacja.

Kostrubiec, J. (2008). Koncepcja „typu idealnego” w teorii Georga Jellinka i Maxa Webera. Szkic porównawczy. W: R.M. Małajny (red.), Konstytucjonalizm a doktryny polityczno-prawne. Najnowsze kierunki badań (s. 21-30). Katowice: Wydawnictwo Uniwersytetu Śląskiego.

Linz, J.A., Stepan, A., Gunther, R. (1995). Democratic Transition and Consolidation in Southern Europe, with Reflections on Latin America and Eastern Europe. W: R. Gunther, P.N. Diamandouros, H.J. Puhle (red.), The Politics of Democratic Consolidation. Southern Europe in Comparative Perspective (s. 77-123). Baltimore and London: The Johns Hopkins University Press.

Markowski, R. i in. (2012). Polskie Generalne Studium Wyborcze 2011 [PGSW]. Pobrane z: http://www.ads.org.pl/opis-szczeg.php?id=90.

Merkel, W. (1998). The Consolidation of Post-Autocratic Democracies: A Multi-level Model. Democratization, 5(3), 33-67.

Merkel, W. (1999). The Consolidation of Post-autocratic Regimes: A Multilevel Model. W: Ch. Moon, J. Mo (red.), Democratization and Globalization in Korea Assessments and Prospects. Seul, Korea: Yonsei University Press.

Merton, R.K. (1938). Social Structure and Anomie. American Sociological Review, 5(3), 672-682.

Merton, R.K. (2002). Struktura społeczna i anomia. W: R.K. Merton, Teoria socjologiczna $i$ struktura społeczna (s. 197-255). Warszawa: Wydawnictwo Naukowe PWN.

Mider, D. (2012). Cyberentuzjaści, cybermaruderzy czy cybermalkontenci? Badanie postaw polskich internautów wobec zastosowań Internetu w polityce. Studia Politologiczne, 26, 41-80. 
Mider, D. (2014). Wymiar społeczny konsolidacji demokracji w Polsce. Typologia postaw wobec systemu politycznego. W: J. Garlicki (red.), Legitymizacja transformacji i systemu politycznego w Polsce, Warszawa: Dom Wydawniczy Elipsa.

Mills, Ch.W. (1965). Białe kotnierzyki. Amerykańskie klasy średnie. Warszawa: Książka i wiedza.

O’Donnell, G. (2001). Illusions about Consolidation. W: L. Diamond, M.F. Plattner (red.), The Global Divergence of Democracies (s. 113-130). Baltimore and London: The Johns Hopkins University Press.

Olsen, M.E. (1968). Two Categories of Political Alienation. Social Forces, 47, 288-299.

Pawłowski, T. (1986). Tworzenie pojęć w naukach humanistycznych. Warszawa: Państwowe Wydawnictwo Naukowe.

Polskie Generalne Studium Wyborcze 2011 [PGSW]. Pobrane z: http://www.ads.org.pl/ opis-szczeg.php?id=90.

Pridham, G. (2000). The Dynamics of Democratization. A Comparative Approach. Baltimore and London: The Johns Hopkins University Press.

Przeworski, A. (1991). Democracy and the Market. Political and Economic Reforms in Eastern Europe and Latin America. Cambridge: Cambridge University Press.

Reykowski, J. (1993). Zmiany systemowe a mentalność polskiego społeczeństwa. W: J. Reykowski (red.), Wartości i postawy Polaków a zmiany systemowe (s. 9-48). Warszawa: Wydawnictwo Instytutu Psychologii Polskiej Akademii Nauk.

Rustow, D.A. (1970). Transitions to Democracy: Toward a Dynamic Model. Comparative Politics, 2(3), 337-363.

Schedler, A. (1997). Concepts of Democratic Consolidation (referat konferencyjny). Latin American Studies Association (LASA). Meksyk.

Schedler, A. (1998). What Is Democratic Consolidation? Journal of Democracy, 9(2), 91- 107.

Schmitter, P.C. (1992). The Consolidation of Democracy and Representation of Social Groups. American Behavioral Scientist, 35(4-5), 422-449.

Schmitter, P.C. (1994). The Proto-Science of Consolidology: Can It Improve the Outcome of Contemporary Efforts at Democratization? Politikon, 12:2(21), 15-27.

Schmitter, P.C. (1995). Is It Safe for Transitologists and Consolidologists to Travel to the Middle East and North Africa? Stanford: artykuł niepublikowany.

Schmitter, P.C., Guilhot, N. (2000). From Transition to Consolidation. Extending the Concept of Democratization and the Practice of Democracy. W: M. Dobry (red.), Democratic and Capitalist Transitions in Eastern Europe. Lessons for the Social Sciences (s. 131-146). Dordrech, Boston, Londyn: Kluwert Academic Publisher.

Schmitter, P.C., Santiso J. (1998). Three Temporal Dimensions to the Consolidation of Democracy. International Political Science Review, 19(1), 69-82.

Sobczyk, M. (2002). Statystyka. Warszawa: Wydawnictwo Naukowe PWN

Szczupaczyński, J. (1996). Elity władzy i demokratyczna konsolidacja. W: T. Klementewicz (red.), Trudna sztuka polityki. Szanse, ryzyko, btąd. Warszawa: Dom Wydawniczy ELIPSA.

Szmatka, J. (2008). Małe struktury społeczne. Warszawa: Wydawnictwo Naukowe PWN. Tatarkiewicz, W. (1951). Pojęcie typu w sztuce. W: W. Tatarkiewicz (red.), Skupienie i marzenie. Studia z zakresu estetyki. Kraków: Wydawnictwo M. Kot. 
Wasilewski, J. (2001). Konsolidacja demokracji: aspekty instytucjonalne i spoteczne. W: E. Hałas (red.), Rozumienie zmian społecznych (s. 245-273). Lublin: Towarzystwo Naukowe Katolickiego Uniwersytetu Lubelskiego.

Weber, M. (1904). Die 'Objektivität' sozialwissenschaftlicher und sozialpolitischer Erkenntnis. W: Archiv für Sozialwissenschaft und Sozialpolitik (s. 19, 22-87). Tübingen: J.C.B. Mohr (Paul Siebeck).

Weber, M. (1904). Die protestantische Ethik und der 'Geist' des Kapitalismus. W: Archiv für Sozialwissenschaft und Sozialpolitik (s. 20, 1-54). Tübingen: J.C.B. Mohr (Paul Siebeck).

Wesołowski, W. (1988). Weberowska koncepcja legitymizacji - ograniczenia i kontynuacje. W: A. Rychard, A. Sułek (red.), Legitymizacja. Klasyczne teorie i polskie doświadczenia (s. 33-66). Warszawa: Polskie Towarzystwo Socjologiczne, Uniwersytet Warszawski,

Woźniak, J. (1990). Logiczna analiza pojęć typologicznych. Warszawa: Znak Język Rzeczywistość.

Yule, G.U., Kendall, M.G. (1966). Wstęp do teorii statystyki. Warszawa: Wydawnictwo Naukowe PWN. 